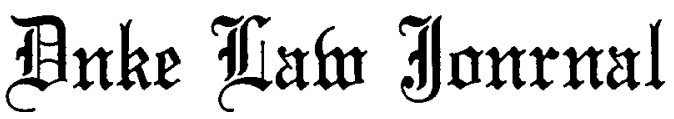

\begin{tabular}{lll}
\hline VOLUME 1982 & APRIL & NUMBER 2 \\
\hline
\end{tabular}

\section{A CRITICAL GUIDE TO THE REGULATORY FLEXIBILITY ACT*}

\author{
PAUL R. VERKUIL**
}

I. INTRODUCTION................................ 214

II. ASSUMPTIONS UNDERLYING THE REgULATORY

FleXIBILITY ACT.............................. 215

A. Historical Concerns for Small Business ............. 216

B. The Relationship Between Regulation and the Health of

Small Business ................................ 219

1. The Importance of Small Business .............. 219

2. Diseconomies of Regulatory Scale .............. 220

C. The Problem of "Deregulating" Small Business ....... 223

1. The Conceptual Problems .................... 223

2. Congressional and Administrative Techniques for Adjusting Regulations to Size of Entity: "Tiering". 225

III. LEgISLATIVE BACKGROUND AND OVERVIEW ........... 226

A. A Brief Legislative Review ..................... 227

B. Overview of the RFA ......................... 229

IV. ANalysis and Critique of Pivotal Provisions ....... 231

A. The Definitional Components of "Small Entities" ..... 232

1. The Meaning of "Small Organization"........... 232

a. Legislative Guidance ...................... 233

b. The Problems of Applying the Definition to Colleges and Universities .................. 234

* Copyright, Paul R. Verkuil 1982. This article is based on a report prepared for the Administrative Conference of the United States. The views expressed herein are those of the author and not necessarily those of the Administrative Conference.

** Dean and Professor of Law, Tulane Law School; A.B., William \& Mary; L.L.B. 1967, University of Virginia; L.L.M. 1969, New York University; M.A. 1969, New School; J.S.D. 1972, New York University. 
2. The Meaning of "Small Governmental Jurisdictions ................................. 237

B. Agencies and Rules Covered by the RFA ........... 238

1. What is a Section 553 Rule?................... 239

2. The Meaning of "Other Law" ................. 240

C. The Certification Process....................... 241

1. Legislative Background to the Certification Process ................................... 242

2. Administrative Implementation of the Certification Process ...................................... 243

a. The Meaning of "Significant Economic Impact" 244

b. The Meaning of "Substantial Number of Small Entities"

D. Formulating the Initial and Final Regulatory Flexibility Analyses

1. The Effect of Contradictory Substantial Law ...... 247

2. The Analytical Techniques Required or Encouraged by the RFA ................................

3. The RFA's Relationship to Executive Order 12,291 and to the Paperwork Reduction Act ............ 252

a. The RFA and Executive Order 12,291 ........ 253

b. The RFA and the Paperwork Reduction Act .... 255

E. Reviewing Existing Rules and Establishing Agendas.... 257

F. The Role of Judicial Review ...................... 259

1. Legislative Background ....................... 260

2. Problems of Interpretation ................... 262

G. The Role of the Office of Advocacy ............... 264

1. The Chief Counsel's Monitoring Role ............. 264

2. The Personnel Needs of the Office of Advocacy .... 265

3. The Office of Advocacy and the OMB........... 266

V. RELATIONSHIP OF THE RFA TO THE REgULATORY

REFORM MOVEMENT............................. 267

A. The Regulatory Reform Proposals................ 267

B. The RFA and Regulatory Reform ................ 269

VI. Conclusion.................................. 271

\section{INTRODUCTION}

The Regulatory Flexibility Act (RFA), ${ }^{1}$ enacted with little fanfare in the closing days of the Carter administration, imposes important

1. 5 U.S.C. $\$ \S 601-612$ (Supp. IV 1980). 
new responsibilities on agencies that declare policy througl rulemaking. For example, such agencies must now perform "regulatory flexibility analyses" as part of the rulemaking process. ${ }^{2}$ As an additional complication to rulemaking, the RFA represents part of a central theme of regulatory restraint that will exist through the 1980's and that will ensure, in the words of President Carter, that "regulation gives Americans their money's worth." 3 In effect, Congress is now telling the regulator to "heal thyself" through careful and cautious pohicynaking.

The RFA is testimony to the political effectiveness of the sinall business lobby both inside and outside of government; indeed, the RFA was the only regulatory-analysis proposal to become law in the regulatory-reform-minded Ninety-sixth Congress. ${ }^{4}$ The RFA is not, however, the only regulatory-analysis scheme to emerge from the recent regulatory-reform movement. A Carter administration executive order 5 introduced the concept of regulatory analysis to executive agencies and President Reagan has refined the concept with his own executive order, which mandates cost-benefit analysis. ${ }^{6}$ The Paperwork Reduction Act ${ }^{7}$ reduced for all agencies the reporting burden of complying with regulations. Moreover, the Nimety-seventh Congress is considering generic regulatory-reform proposals that mandate regulatory analysis. ${ }^{8}$ Thus, the RFA is both a harbinger and microcosm of regulatory reform.

This article is a guide to the RFA. The article explores the assumptions underlying the RFA and analyzes its provisions. In addition, the article studies the RFA's relationship to other regulatoryanalysis efforts and offers suggestions for integrating the RFA into the general scheme of regulatory reform.

\section{ASSUMPTIONS UNDERLYING THE REgUlatory FlEXIBILITY ACT}

The RFA is a stunning achievement for the small business community and its representatives in government because it requires virtu-

2. See notes 179-206 infra and accompanying text.

3. The White House, Regulatory Reform: President Carter's Program 2 (1980).

4. Id. 26.

5. Exec. Order No. 12,044, 3 C.F.R. 671 (1978), revoked by Exec. Order No. 12,291, 46 Fed. Reg. 13,193, reprinted in 5 U.S.C. app. $\$ 601$, at 124 (Supp. IV 1980).

6. Exec. Order No. 12,291, 46 Fed. Reg. 13,193, reprinted in 5 U.S.C. app. $\$ 601$, at 124 (Supp. IV 1980). For a discussion of the Executive Order and the RFA, see notes 228-42 infra and accompanying text.

7. 44 U.S.C. $\$ \S 3501-3520$ (West Supp. 1980). For a discussion of the Act, see notes 243-54 infra and accompanying text.

8. See notes 300-313 infra and accompanying text. 
ally all government policymaking to be sensitive to small business concerns. This success is the culmination of the resistance of small business to increasing government regulation. Because of earlier legislative successes, small busmess was ready to take immediate advantage of an emerging movement away from government regulation. Its position was strengtliened by the convincing argument that small business was bearing a disproportionate share of the regulatory burden on business and industry.

\section{A. Historical Concerns for Small Business.}

Simce the passage of the Small Busmess Act (the Act) ${ }^{9}$ in 1953, Congress has shown a special solicitude for the problems of small business. The Act provided small business with assistance in receiving government loans, in obtaining government contracts, and in securing technical and managerial know-how. It also established the Small Business Administration (SBA), which was to carry out the purposes of the Act under the direction of the President. ${ }^{10}$ The initial thrust of the SBA was to study whether defense-procureinent programs unfairly discriminated agamst or imposed undue burdens on small business and to recommend appropriate adjustments. ${ }^{11}$ In 1958 Congress expanded the SBA's protective role by requiring government to transact a fair proportion of its purchases and sales with small busmess. ${ }^{12}$ This legislation also permitted the use of variable size standards to define "small business" for procurement purposes. ${ }^{13}$ Congress contimued to recognize the needs of small business as the impact of government grew beyond defense procurement into other areas of the economy. ${ }^{14}$

By 1974 the overall loan, guaranty, and investment ceilings for

9. Pub. L. No. $83-163,67$ Stat. 232 (1953) (current version at 15 U.S.C. $\$ \S 631-647$ (1976 \& Supp. IV 1980)).

10. See 5 U.S.C. $\S 633$ (a) (1976).

11. See Small Business Act of 1953, Pub. L. No. 83-163, § 216, 67 Stat. 232.

12. Small Busmess Act Amendments of 1958, Pub. L. No. 85-536, $\S 2$ (a), 72 Stat. 384 (codified at 15 U.S.C. § 637 (1976 \& Supp. IV 1980)).

13. See id. The term had previously been construed to mean firms with fewer than 500 employees. An interageucy task force then determined that size standards should vary by industry. Thus, in the case of oil refineries, it was suggested that "small" refineries would be those with fewer than 1,000 rather than 500 employees. See S. REp. No. 1714, 85th Cong., 2d Sess. 7-8 (1958), reprinted in [1958] U.S. CODE CONG. \& AD. NEws 3071, 3077-78.

14. The Small Business Investment Act of 1958, Pub. L. No. 85-699, 72 Stat. 689 (codified at 15 U.S.C. $\$ \S 661-696$ (1976 \& Supp. IV 1980)), encouraged the creation of privately-owned small busmesses. The Small Busimess Act Amendments of 1961, Pub. L. No. 87-305, §9, 75 Stat. 666 (codified at 15 U.S.C. $§ 636$ (d) (1976)), expanded the avaliability of grants to state agencies and to universities for researching and counseling small busimess enterprises. The Housing Act of 1961, Pub. L. No. 87-70, § 305, 75 Stat. 149, anended section 7(b) of the Small Business Act, 15 U.S.C. $\S 636(b)(3)$ (1976), to permit loans to small businesses displaced by urban-renewal activity. 
small business had reached $\$ 6$ billion. ${ }^{15}$ Nevertheless, the small business constituency grew dissatisfied with the performance of the SBA. Small business trade associations, suggestimg the SBA was mismanaged, claimed it no longer represented the small business community. ${ }^{16}$ They called for the appointment of a Chief Counsel for Advocacy, creating a new position within the SBA, to serve as ombudsinan to protect the interests of small business. ${ }^{17}$ This remarkable notion - that an agency with a single constituency needed another organization within it to protect the interests of that constituency - garnered the support.of Congress within two years.

In 1976 Congress established the Office of Advocacy. The Office would be headed by a Chief Counsel with broad powers to examine both the needs of and the burdens on small busmess. ${ }^{18}$ The Chief Counsel's role imcluded the evaluation of complaints against the SBA and other federal agencies and the preparation of recommendations concerning those complamts. Specifically, the Chief Counsel was admonished to "measure the direct costs and other effects of government regulation on small businesses; and make legislative and nonlegislative proposals for eliminating excessive or unnecessary regulations of small businesses." 19

This change marked a dramatic shift of emphasis for the SBA, from protectimg small busmess against a harsh economy to protecting it against a harsh bureaucracy. Undoubtedly reflecting a general discontent with government regulation, ${ }^{20}$ especially the health, safety, and environmental regulations of the $1970 \mathrm{~s}^{21}$ the shift provided the intellectual predicate for the legislation that would create the RFA four

15. Small Business Act Amendments of 1974, Pub. L. No. 93-386 § 2(a)(3), 88 Stat. 742 (codified at 15 U.S.C. $\$ 633$ (c)(4) (1976)), as amended by Act of Aug. 4, 1977, Pub. L. No. 95-89, $\S 101$ (c), 91 Stat. 553 (codified at 15 U.S.C. $\S 633$ (Supp. IV 1980)).

16. See The Regulatory Flexibility Act: Hearings on S. 1974 Before the Subcomm. on Administrative Practices and Procedures of the Senate Comm. on the Judiciary, 95th Cong., 1st Sess. 142 (1977) (answers to questions by James McKevitt) [hereinafter cited as 1977 Senate RFA Hearings].

17. See H. R. REP. No. 1178, 93d Cong., 2d Sess. 7, reprinted in [1974] U.S. CODE CoNG. \& AD. NEws 4500, 4507-08.

18. Act of June 4, 1976, Pub. L. No. $94-305,90$ Stat. 668 (codified at 15 U.S.C. $\$ \$ 634 a-634 \mathrm{~g}$ (1976 \& Supp. IV 1980)).

19. 15 U.S.C. $\$ 634 \mathrm{~b}(3)$ (1976). By this legislation the Chief Counsel was made something of a knight-errant for small business throughout government. All government agencies and departments were directed to furnish the Chief Counsel "such reports and other information as he deems necessary to carry out his functions." Id. $\$ 634 \mathrm{e}$.

20. See, e.g., Exec. Order No. 11,821, 39 Fed. Reg. 41,501 (1974) (requiring executive agencies to consider the economic impact of certain rules and regulations on the busimess community).

21. See, e.g., 122 CoNG. REC. 13,781 (1976) (citing OSHA and ERISA as bills written "without adequate consideration of small business problems" and which made a small business advocate necessary) (remarks of Rep. Conte). 
years later.22 A Senate report to the White House in late 1979 set the stage for this development by emphasizmg that "[1n]any small business groups have suggested that SBA's only role should be to act as an advocate for small business within the Federal Government."23 The White House Conference on Small Business, chaired by Arthur Levitt of the American Stock Exchange, was a grass-roots organization of small busimess people estabhished to formulate and to debate the critical issues facing small business in the 1980's. ${ }^{24}$ The Conference made sixty recommendations, many of which had a decidedly anti-regulation thrust. ${ }^{25}$ One of the Conference's six specific policy goals for government was the elimination or reduction of onerous regulations and reporting requirements. ${ }^{26}$

It is difficult to overstate the impact the Conference liad on the White House and on Congress in the election year of 1980. In that year four important pieces of presidentially supported small business legislation emerged from Congress. The Small Business Economic Policy Act of $1980^{27}$ mandates the coordimation of all federal departments and agencies in fostering the economic interests of small business and requires the President to submit an annual report to Congress assessing the impact of federal laws and policies on small busimess. The Equal Access to Justice Act $^{28}$ provides certain prevailing parties with recovery of attorneys' fees, witnesses' fees, and other costs resulting froin litigation agamst the United States. The eligible parties include those who meet small business size and asset standards. ${ }^{29}$ The purpose of this Act is to remove any deterrents a small business (or other qualifying litigant) may face im litigating against administrative agencies. ${ }^{30}$ Further-

22. Because Congress did not confirm the first Chief Counsel, Milton Stewart, until July 1978, the Office of Advocacy did not begin its work until almost two years after Congress established it. See generally Nomination of Milton Stewart to be Chief Counsel for Advacacy of the SBA: Hearings Before the Senate Select Comm. on Small Business, 95th Cong., 2d Sess. (1978).

23. Senate Select Comm. on Small Business, 96th Cong., Ist Sess., Discussion and Comments on the Major Issues Facing SMall Business 52 (Comm. Print 1979) [hereinafter cited as Senate Select Comm.].

24. White house Commission on Small Business, Report to the President: AMERICA's SMALI BUSINESS ECONOMY 41-43 (1980) [hereinafter cited as White House COMM'N].

25. The Report devoted 10 of its 60 recommendations to government regulation, paperwork, and economic policies that concerned sinall business. See id. 53-54.

26. Id. 29.

27. 15 U.S.C. $\$ \S 631 \mathrm{a}-631 \mathrm{lb}$ (Supp. IV 1980).

28. Pub. L. No. $96-481, \S 203,94$ Stat. 2325 (codified at 5 U.S.C. $\$ 504$ (Supp. IV 1980) and other sections in titles 15,28 and 42 U.S.C.).

29. The size standards exclude individuals with a net worth in excess of $\$ 1$ million and businesses with a net worth in excess of $\$ 5$ million or with more than 500 employees. 5 U.S.C. $\S 504(\mathrm{~b})(1)$ (B) (Supp. IV 1980).

30. Pub. L. No. 96-481, § 202(c)(1), 94 Stat. 2325 (1980). 
more, according to the SBA, the Act is to make government agencies cautious about bringing actions against small busmesses. ${ }^{31}$ The Paperwork Reduction Act, ${ }^{32}$ the result of a four-year effort to reduce the paperwork burden the federal government imposes on business, ${ }^{33}$ gives the Office of Management and Budget (OMB) control over the amount of paperwork generated by executive and independent agencies. Although the Act is not limited in its effect to small business, it was one of the specific recommendations of the White House Conference on Small Busmess. ${ }^{34}$ Few regulations are more strongly objected to by the sinall busmess community than those increasing the burden of the federal government's reporting and record-keeping requirements. ${ }^{35}$ The RFA, the fourth piece of small business legislation passed by Congress in $1980,{ }^{36}$ was a response to concerns about the differential impact of regulatiou on small busmess, concerns central to the recommendations made by the White House Conference on Small Business. The legislative successes of 1980 give substance to Article 1 of the Small Business Bill of Rights: "The right to start, own, and manage a business without government interference." 37

\section{B. The Relationship Between Regulation and the Health of Small Business.}

1. The Importance of Small Business. The small business sector (as defined by the SBA) constitutes about ninety-eight percent of all uonfarnn businesses and accounts for thirty-nine percent of the gross national product. ${ }^{38}$ It employs over 100 million people, or fifty-eight percent of all business employment, ${ }^{39}$ and is frequently the entry point for new ventures, which create new jobs. Furthermore, there is reason

31. See SBA, ANNuAl Report 22 (1980).

32. 44 U.S.C.A. $\$ \S 3501-3520$ (West Supp. 1981).

33. A good overview of previous paperwork-reduction efforts is provided in Neustadt, Taming the Paperwork Tiger - An Experiment in Regulatory Management, Regulation, Jan./Feb. 1981, at 28.

34. White House COMM'N, supra note 24 , at 53 (recommendation 43).

35. For example, the Senate Select Committee on Small Business concluded that "[i]mproving government regulations, abolishing unnecessary regulations and reducing paperwork are goals that can and must be met." SENATE SELECT Comm., supra note 23, at 49.

36. Pub. L. No. 96-354, 94 Stat. 1165 (1980) (codified at 5 U.S.C. $\&$ 601-612 (Supp. IV 1980)). Another important piece of small business legislation enacted in 1980 was the Small Business Investment Incentive Act of 1980, Pub. L. No. 96-477, 94 Stat. 2275 (codified in various sections of 15 U.S.C.).

37. See WhIte House Comm'N, supra note 24, at 49.

38. U.S. SMall Business Administration, Facts About SMall Business and the U.S. SMALl BUSINESS ADMINISTRATION 3-4 (1981).

39. Id. The SBA definitions of small businesses vary by industry and are elaborately developed in Standard Industrial Classifications. See OfFice of Advocacy, U.S. SMaLl Business 
to believe that the rate of innovation in small businesses is higher than in large businesses. ${ }^{40}$ Many of our most innovative high technology companies sucl as those in the microprocessor industry began as small businesses. In times of increasing world-wide competition for mdustrial leadership, this source of technological innovation should be encouraged. Over the last twenty years, however, the small business sector of the economy has shrunk in comparison with the large business sector. ${ }^{41}$ It is probably impossible to determine the optimal portion of the economy to be constituted by small businesses, for to some extent the growth of a complex economy may portend a shift to larger business entities as small businesses mature. Because there is no economic reason for government to promulgate policies that intentionally or unintentionally retard small busmess development, government policies unfavorable toward small busmess have become an increasing concern of the small busimess community. ${ }^{42}$

2. Diseconomies of Regulatory Scale. The point at which a business entity achieves economies of scale determines the optimum size of such an entity in a competitive, free-market economy. At that point growth is no longer necessary to produce goods more efficiently. Depending on the nature of the industry and its product mix, efficient size may or may not make a firm a small business by SBA definitions. Aside from the economic forces, often produced by government regulation, that increase firm size, there appear to be noneconomic forces, also often produced by government regulation, that require a firm to grow or, rather, penalize a firm for not growing.43

Association, The Study of SMall Business, Pt. II (1977). Generally speaking, firms having fewer than 500 einployees or less than $\$ 5$ million in sales are classified as sinall businesses.

40. Determining how firm size affects the rate of innovation is not an easy matter. The SBA has conducted studies that indicate big business is less innovative than small busimess. See GeLLman Research Assoc., Inc., The Relationship BetweEn Industrial Concentration and Technological Innovation, (SBA Contract No. 2652-0A-79, Sept. 16, 1981) (Innovations per million employees: small firms-157; large firms-64) (on file with Duke Law Library). The SBA also recommends further study of the impact of increased merger activity on the rate of innovation. See 1 U.S. Small Business Administration, AnNual Report-FY 1980, 14.

41. In 1960, sunall and medium size manufacturers accounted for $50 \%$ of the manufacturing industry's assets; this portion had dropped to $33 \%$ by 1972 . In 1953, $15 \%$ of the nation's gross . private doinestic investment was in small, nonfarm, noncorporate businesses, but in 1973 small business accounted for only 7.5\%. 122 CoNG. REC., 15,009 (1976) (remarks of Rep. McCollister).

42. Representative McCollister's comment on government pohicy is interesting: "If our national pohicy is to promote small business, that policy is failing." See also JOEL POPKID \& Co., Strategy for a Micro Data Base for SMall Business - Progress Report, (SBA Contract No. 2624-OA-79, Mar. 12, 1980) (on file with Duke Law Library).

43. See 1977 Senate RFA Hearings, supra note 16, pt. 1, at 126 (testimony of Milton Kafoglis). 
Laws and regulations, intended for both large and small firms, are having an increasingly negative effect on the growth of small business. This negative effect occurs in two ways: because small businesses have fewer units of output over which to spread regulatory costs, regulatory costs are higher per unit of output; and sinall businesses lack requisite size to take advantage of economies of scale in regulatory-compliance, personnel, and data systeins. ${ }^{44}$

Tax laws and regulations are a particular problem. Representative John McCollister of Nebraska recently highlighted the tax problems of small business:

Perhaps the most devastatimg form which Federal antismall business discrimination takes is found in the tax code. The coinplexity of the code itself overwhelms small busmessmen who lack trained legal and accounting departments and can ill afford to hire high priced consultants. In the area of the code's capital recovery provisions, for example, small business typically utilizes straight-line depreciation because they cannot afford the time or just plain cannot figure out how to use the more complex capital recovery devices which could give them a better tax situation. Large corporations, of course, are able to utilize the more complicated provisions and, as a result, pay lower effective tax rates than small businesses. As a class, the 100 largest corporations pay an effective rate up to 50 percent. Two years ago, a congressional study of corporate tax rates found that the $\mathrm{Na}$ tion's largest 143 corporations paid an average tax rate of 23.4 percent. The average rate for all corporations was 33.4 percent. 45

The complexity of the tax laws inevitably seems to favor larger businesses. Although some recent reforms in the tax laws have benefitted small businesses, ${ }^{46}$ the overall impact continues to be negative.

Other agencies and programs that substantially burden sinall businesses include the Environmental Protection Agency (EPA), the Department of Energy (DOE), the Occupational Health and Safety Administration (OSHA), and the Einployee Retirement Incoine Security Act (ERISA). ${ }^{47}$ EPA's effluent-reduction regulations have a greater impact on small business than on large business because the regulations mandate compliance techniques that are less coinpatible with the pro-

44. See 1977 Senate RFA Hearings, supra note 16, pt. 3, at 350-355 (remarks of Alfred Dougherty).

45. 122 CONG. REC. 15,009 (1976) (remarks of Rep. McCollister).

46. One example is the rate reduction on taxes of capital gains, which has encouraged the formation of venture-capital firms that invest in small business. See Economic Recovery Tax Act of 1981, Pub. L. No. 97-34, \& 102, 95 Stat. 186.

47. Pub. L. No. 93-406, 88 Stat. 829 (1974) (codified in various sections of titles 5, 18, 26, 31, and 42 U.S.C.). 
duction technologies of small firms. ${ }^{48}$ DOE's record-keeping requirements concerning oil and gas prices and volume are vague and unintelligible. ${ }^{49}$ OSHA is faulted for its national-consensus standards, which burden small businesses that lack technical expertise to interpret the requirements. ${ }^{50}$ The Internal Revenue Service (IRS) is criticized for promulgating unreasonable and coinplicated ERISA regulations that, rather than protecting employee pension rights, have the practical effect of terminatimg pension plans for einployees of small businesses. 51

Not only does the substance of regulatory laws frustrate small busmess, but small business also suffers acutely, on a cost-per-unit basis, from completing reports required by the IRS and other government agencies. ${ }^{52}$ Studies show that the average cost of coinpleting government forms per employee and per dollar of sales drops dramatically as firm size grows. ${ }^{53}$ Although the IRS is the traditional nemesis of small busincss in this regard, ${ }^{54}$ the new government agencies of the 1970 s such as the Consumer Product Safety Commission, OSHA, and the Equal Employment Opportunity Commission, have refined mandatory reporting into a fine art. ${ }^{55}$ Mandatory reporting has become a favorite tool of governinent, perhaps because it is a inethod of shifting and dispersing compliance costs from the agencies to the regulated entities. The small business community has objected to federal paperwork requirements for a variety of reasons. Most objections concern the number and complexity of reports, their lack of clarity, their frequency,

48. Small Business Impact Bill: Hearings on H.R. 7739 and H.R. 10632 Before the Subcomm. on Special Small Business Problems of the House Comm. on Small Business, 95th Cong., 1st Sess. $89-96$ (1978) (remarks of James Miller) [hereinafter cited as Small Business Impact Bill Hearings].

49. Small Business Impact Bill Hearings, supra note 48, at 314-18 (statement of Robert Amori).

50. Id. 127-29 (statement of James McKevitt).

51. Id. at 123-24 (statement of James McKevitt).

52. The cost to small business of coinplying with regulations has been described as a "regressive tax" because small business bears the same paperwork burden as large, multinational companies. SBA's Paperwork Measurement and Reduction Program: Hearings Before the Senate Select Comm. on Small Business, 96th Cong., 1st Sess. 50 (1980) (statenent of Milton Stewart) [hereinafter cited as Paperwork Reduction Hearings].

53. See The Regulatory Flexibility Act: Joint Hearings on S. 1974 and S. 3330 Before the Subcomm on Administrative Practice and Procedure, Senate Comm. on the Judiciary and Senate Select Comm. on Small Business, 95th Cong., 2d Sess., pt. 2, at 432-33 (1978) (Appendix "F").

54. It is estimated that $70 \%$ to $80 \%$ of the paperwork required of sinall busimess emanates froin the IRS and state tax agencies. Paperwork Reduction Hearings, supra note 52, at 84.

55. The SBA has estimated that small business expends 130 million man-hours annually in filling out non-IRS forms. IRS paperwork requirements amount to 1,600 million man-hours, more than the total employee production of General Motors. Federal Paperwork Requirements: Hearings Before the Subcomm. on Government Regulation and Paperwork, Senate Select Comm. on Small Business, 96th Cong., 1st Sess. 2-3 (1979) (remarks of Sen. Hatch). 
and the need for professional help from accountants and lawyers to complete them. ${ }^{56}$

The plight of small business is that the regulatory goals of society, ostensibly equal im impact, disproportionately burden small business. To some extent, small business is merely suffering the unequal consequences of equal treatment expounded by Anatole France. ${ }^{57}$ But then, as now, when such treatment results in serious frustration of personal initiative, it is bound to become a subject for reform.

\section{The Problem of "Deregulating" Small Business.}

Much of the current "deregulation" movement has been inspired by the small busmess commumity's unhappiness with the existing pattern of regulation. Agencies and Congress are aware of the regulatory problem of equal treatment of unequals and attempted to institute differential reporting and compliance standards based on size, even before the advent of the Regulatory Flexibility and Paperwork Reduction Acts.

1. The Conceptual Problems. It would be satisfactory to almost everyone if one could prorate the costs of every government program according to company size. ${ }^{58}$ But the complexity of regulation makes it virtually impossible to isolate compliance costs. ${ }^{59}$ Indeed, any effort to do so would, as with atteinpts to design a regulatory budget, ${ }^{60}$ embroil government in additional regulation of an unknown magnitude. Therefore, reform solutions have suggested releasing small businesses from certain regulatory requirements imposed on larger businesses or a reduction of responsibilities imposed by those requirements. But these solutions are not problem free.

Exemption from regulation may amount to economic protectionisin for small business, with resulting undesirable consequences. The

56. Paperwork Reduction Hearings, supra note 52, at 33-34 (statement of Milton Stewart). Mr. Stewart, Chief Counsel for the Office of Advocacy of the SBA, refers to these objections as small busimess' "paperwork lament." Id.

57. Anatole France berated "the majestic equality of the law that forbids the rich as well as the poor to sleep under bridges, to beg in the streets and to steal bread." A. FRANCE, LE LYS Rouge 117 (1894). For the view that this criticism of law undermines impartiality of justice, see F. HAYEK, THE CONSTITUTION OF LIBERTY 234-49 (1960).

58. Because smaller entities may "cost" more to regulate than larger entities, economies of regulatory scale may exist both in the regulator and the regulated.

59. The State of Washington conducted one of the few empirical studies on the costs of comphance with regulations. The study concluded that busmesses with less than 50 employees have inordinately higher compliance costs than those businesses with over 50 employees. COLE \& SUMmers, Costs of Complance In SMall and Moderate-Sized Businesses, Report to the SBA (1980). The results of this study suggest that other studies of this type, with larger sample sizes, would be profitable. See id. 28.

60. See Eads, Harnessing Regulation - The Evolving Role of White House Oversight, REGULATION May/June 1981, at 19. 
health of small business is determined not only by the number that succeed, but also by the number that fail. To stifle the creative forces arising from the possibility of failure inay serve only to keep inefficient entities alive. Moreover, the natural process of business growth is hampered if sinallness is rewarded by deregulation, because firms are then encouraged to maintain a sub-optimal economic size. ${ }^{61}$ While discouraging the growith and capital formation necessary for expansion and product developinent on the one hand, protective deregulation encourages nonproductive organizational devices to take advantage of government-established firm size limitations on the other. ${ }^{62}$

Another serious problem with deregulation of small business is the potential frustration of the substantive goals of regulation. The purpose of health, safety, environmental, and consuner regulation is to protect individuals in the public and in the work force. It is cold coinfort to the miner who contracts black lung disease or to the textile worker who inhales cotton dust that he is less protected because his employer qualifies as a small business. ${ }^{63}$ Froin a public policy standpoimt, protection against these kinds of hazards must be stated in absolute terms, even when absolute protection is impossible despite great expenditures. This is the lesson of OSHA's refusal, accepted by the Supreme Court, ${ }^{64}$ to adopt cost-benefit analyses in determining acceptable levels of worker exposure to harmful substances.

Furthermore, there is an equity problein with exempting small business from regulation - the problein of where to draw the line. At the margin, size standards draw meaningless distinctions, ${ }^{65}$ but the reg-

61. Congress has been concerned about encouraging smallness for these reasons. Congress does "not want to create any disencentives to ecouomic growth." 126 CoNG. REC. H8461 (daily ed. Sept. 8, 1980) (remarks of Rep. Seiberling).

62. For example, the House discussion of the need for the RFA pointed out that DOE's crude oil entitlement program allows "small refineries" to purchase crude oil at reduced prices. As a consequence, 37 of 38 new refineries built between 1974 and 1977 were designed to process less than 40,000 barrels per day, the threshold of the entitlements program, whereas the minimum technologically efficient refinery size is 175,000 barrels per day. See 126 CoNG. REC. H8467 (daily ed. Sept. 8, 1980).

63. Lack of protection can occur not only because protective legislation does not to apply to the small enterprises involved, but also because agencies internally inodify enforcement resources and reporting requirements to reflect size considerations. Also, as Representative Seiberling has noted, Congress must be careful not to provide incentives for large busmess to spin off unsafe operations into smaller businesses not subject to strict regulation. This allegedly oceurred in the case of the Allied Chemical plant in Hopewell, Virginia that was the source of keypone contamination in the James River. See 126 CoNG. Rec. H8461 (daily ed. Sept. 8, 1980) (remarks of Rep. Seiberling).

64. See American Textile Mfrs. Inst., Inc. v. Donovan, 452 U.S. 490, 509 (1981).

65. What difference does it make, for example, whether a small business has 499 or 500 employees, or $\$ 4,999,000$ or $\$ 5,000,000$ in sales? The SBA admits that establishing size standards for small business in the middle (or "gray") area is very difficult. The SBA apparently considers 
ulatory benefits they may carry. are no less valuable. The exemption process may therefore be arbitrary in any individual case, ${ }^{66}$ even if courts uphold it. ${ }^{67}$

\section{Congressional and Administrative Techniques for Adjusting Reg-} ulations to Size of Entity: "Tiering." Despite conceptual difficulties, federal statutes and regulations have long acknowledged the relevance of size in determining their coverage. Perhaps the classic example of this deference to size is the "Mrs. Murphy" exemption to the Civil Rights Act of $1968,{ }^{68}$ which renders the housing non-discrimination provisions of the Act inapplicable to owner-occupied units of four families or less. ${ }^{69}$ In this situation, as a nuatter of political expediency as well as potential impact, Congress thought it appropriate to subordinate the public interest against discrimination to individual interests in privacy. ${ }^{70}$

A series of administrative adjustments - often by the agencies most objected to by small business - also seek to reduce the regulatory burden on sinall firms. Soine have taken the form of outright exemptions from compliance, such as OSHA's decision to eliminate reporting burdens for businesses with ten or fewer employees. ${ }^{71}$ Both the Securities and Exchange Commission and the EPA have issued a variety of regulations that provide specific exeinptions for sinall business. ${ }^{72}$ In addition, some agencies have devised innovative regulatory plans that

whether it should assist competition in given industries by including mid-sized firms within its definitions. See Size Standards for Small Businesses: Hearings Before the Subcomm. on General Oversight and Minority Enterprise of the House Comm. on Small Business, 96th Cong., 1st Sess. 17 (1980) (statement of SBA Associate Administrator Roger Rosenberger).

66. Regulatory discrimination based on the size of regulated entities has withstood constitutional challenges based on equal protection claims. See Williamson v. Lee Optical Co., 348 U.S. 483, 489 (1955); Tiguer v. Texas, 310 U.S. 141, 147 (1940).

67. Some courts have specifically upheld SBA size standards, see, e.g., Otis Steel Prod. Corp. v. United States, 316 F.2d 937, 940 (Ct. Cl. 1963), and the SBA's refusal to consider affiliates of large busimesses as "small." See American Elec. Co. v. United States, 270 F. Supp. 689, 691 (D. Hawaii 1967); Springfield White Castle Co. v. Foley, 230 F. Supp. 77, $78-79$ (W.D. Mo. 1964).

68. 42 U.S.C. \& 3603(b)(2)(1976). Mrs. Murphy was the name given to the imaginary constituent whose rooming house would not be subject to the law. See Civil Rights - the President's Program: Hearings on S. 1731 and S. 1750 before the Senate Comm on the Judiciary, 88th Cong., 1st Sess. $31-32$ (1963) (remarks of Sen. Ervin). See also 42 U.S.C. § 2000a(b)(1)(1976) (excluding accommodatious of five rooms or less).

69. See, e.g., Fred v. Kokinokos, 347 F. Supp. 942 , 944 (E.D.N.Y. 1972). The question has been raised whether this exenption also applies to the 1866 Civil Rights Act, 42 U.S.C. § 1982 (1976). See Morris v. Cizek, 503 F.2d 1303, 1304 (7th Cir. 1974) (per curiam).

70. See Note, Public Accomodations: A Justification of Title II of the Civil Rights Act of 1964, 16 W. RES. L. REV. 660, 672 (1965).

71. See Paperwork Reduction Hearings, supra note 52, at 51 (statenent of Milton Stewart).

72. See, e.g., 17 C.F.R. $\$ 230.257$ (1981) (exception for offerings of securities less than $\$ 100,000) ; 40$ C.F.R. $\$ 21$ (1981) (EPA sinall business exeniptions). 
are intended to minimize the impact of regulations on small business. ${ }^{73}$ For example, the EPA's bubble concept allows businesses some flexibility in reducing total emissions by placing an imaginary bubble over an entire plant and demanding only that overall emissions levels meet established standards rather than requiring each stack within the plant to be of the most efficient design. ${ }^{74}$

This metlod for adjusting government regulation to the needs of small busmess is known as "tiering."75 Tiering allows an agency (or in some instances Congress itself) to tailor regulatory requirements to fit the particular needs of the regulated entities. The predominant method of tiering uses the size standards proinulgated by the SBA, which can be used both $\mathrm{m}$ graduated stages and in a smgle division. ${ }^{76}$ In addition to size standards, some agencies have determined appropriate tiers by degree of risk, technological and economic ability to comply, geographical location, and level of federal funding. ${ }^{77}$ In 1981 the Regulatory Council collected 190 examples of tiering permitted by fourteen executive and twelve independent agencies. ${ }^{78}$ This trend will probably contimue as agencies look for ways to meet the objections of their smaller but increasingly influential constituents.

\section{Liegislative BaCKGROUND AND OVERVIEW}

Though the RFA was a congressional response to the complaints of small business about the burderis of federal regulation, its impact is more general, as its placement in Title 5 of the United States Code (ameriding the Administrative Procedure Act. (APA)) ${ }^{79}$ suggests. Emerging from a broad-based concern witl regulatory reforn, the RFA represents not only a triumph of regulatory analysis as a statutory concept, but also a part of a larger, still evolving legislative trend.

73. The SEC, for example, has created an Office of Small Business Policy to review its rules with a view towards minimizing burdens on small busimess.

74. See 126 Cong. Rec. S10,937 (daily ed. Aug. 6, 1980) (discussion in the Senate's sectionby-section analysis of the bill).

75. See generally U. S. Regulatory Council, Tiering Regulations: A Practical GUIDE (1981).

76. In fact, the White House Conference on Small Business recommended that SBA size standards themselves be designed with multiple tiers rather than in a single division. See WHITE HOUSE COMM'N, supra note 24, at 59 (resolution 8).

77. See U.S. REgulatory CouNCIL, supra note 75, at 4-6.

78. Id. $41-54$.

79. 5 U.S.C. $\S \S 551-559,701-706$ (1976 \& Supp. IV 1980). 


\section{A. A Brief Legislative Review.}

Although the RFA quietly appeared at the end of the term of the Nimety-sixth Congress, it has a lengthy and complex legislative history. Senators Culver and Nelson first introduced a bill (S. 1974) entitled "The Regulatory Flexibility Act" in the Nimety-fifth Congress. ${ }^{80}$ Senate hearimgs were held on the bill during 1977 and 1978, resulting in various amendments. ${ }^{81}$ The bill passed the Senate on October 14, 1978, but because of a lack of activity im the House, no further action was taken on the bill during the Nimety-fifth Congress. ${ }^{82}$

At the beginning of the Ninety-sixth Congress, activity on regulatory flexibility imcreased. Senator Culver reintroduced his original bill as S. 299 on January 31, 1979.83 On the same day, Representative Ireland introduced a bill in the House entitled "The Small Business Regulatory Rehief Act," 84 which was similar in purpose to Senator Culver's bill but was cast as an amendment to the Small Business Act. ${ }^{85}$ The Senate and the House extensively examined their respective bills over the next six months. ${ }^{86}$

Simultaneously, other independently conceived legislative efforts were forming that related to the existimg small business efforts. Two omnibus regulatory-reform bills were introduced that applied the concept of regulatory analysis to all administrative agencies. Senator Ribicoff introduced a regulatory-reforn act in the Senate and Representative Rodmo introduced one in the House. ${ }^{87}$ The Carter adminis-

80. S. 1974, 95th Cong., 1st Sess., 123 CoNG. REC. 25,844 (1977).

81. Hearings on S. 1974 as amended were held on October 7, 1977, and August 23, 1978 before the Subcommittee on Administrative Practice and Procedure, which unanimously and favorably reported S. 1974 to the Judiciary Committee on September 9, 1978. See S. REP. No. 1322, 95th Cong., 2d Sess. 2 (1978).

82. Representatives Kastenmeier and Baldus introdnced H.R. 11,376, the House companion bill to S. 1974 on March 8, 1978, but no action was taken on it. The House also had two other bills on small busimess impact before it, but no further activity took place in the House after S. 1974 passed the Senate. See generally Small Business Impact Bill: Hearings on H.R. 7739 and H.R. 10,632 Before the Subcomm on Special Small Business Problems of the House Comm. on Small Business, 95th Cong., 2d Sess. (1978).

83. S. 299, 96th Cong., 1st Sess., 125 CoNG. REC. S907 (daily ed. Jan. 31, 1979) [hereinafter cited as S. 299]. Representatives Kastenmeier, Baldus, and Harkin introduced the House companion bill, H.R. 1971, one week later. 125 CoNG. REC. H556 (daily ed. Feb. 8, 1979).

84. H.R. 1745, 96th Cong., lst Sess., 125 CoNG. Rec. H404 (daily ed. Jan. 31, 1979).

85. 15 U.S.C. $§ \S 631-647$ (1976 \& Supp. IV 1980).

86. See S. REp. No. 878, 96th Cong., 1st Sess. (1980) (accompanying S. 299); H.R. REP. No. 519, 96th Cong., 1st Sess. (1979) (accompanying H.R. 4660). H.R. 4660 became the principal House bill on which hearings centered. It was an expansion of H.R. 1745, and was imtroduced by Representative Gore on June 28, 1979. 125 CoNG. REC. H5420 (daily ed. June 28, 1979).

87. See S. 1291, 96th Cong., 1st Sess., 125 CoNG. REC. S7128 (daily ed. June 6, 1979); H.R. 3263, 96th Cong., 1st Sess., 125 CoNG. REc. H1737 (daily ed. Mar. 27, 1979). 
tration also introduced a comprehensive regulatory-reform bill with regulatory analysis as its centerpiece. ${ }^{88}$

As this activity demonstratcs, regulatory reform was a major theme of the Ninety-sixth Congress. The number of bills and of legislative days devoted to the topic formed an impressive proportion of the Congress' work. ${ }^{89}$ After all the dust had settled, however, only the small business reform bills survived,90 and even those went through considerable debate and change before becoming law.

The major Senate and House bills on regulatory flexibility ${ }^{11}$ (each of which went through extensive hearings) differed in significant ways. The Senate bill amended the APA; the House bill amended the Small Busmess Act.92 The House bill rehed nnore heavily on a select hist of methods (imcluding tiering) for reducing the burden on small busmess, whereas the Senate bill listed its methods as examples and required only that the agency explain its rejection of any inethods. The Senate bill covered small governmental jurisdictions; the House bill did not. Finally, the Senate version as introduced had a limited provision for judicial review, a inatter the House version did not address. ${ }^{93}$

The Senate bill, S. 299, eventually became law when the House passed it without amendinent on September 8, 1980.94 The House held no separate hearings on the Senate bill; rather, it simply adopted the Senate's description and section-by-section analysis of the bill. ${ }^{95}$ The House was content with a three-page "Discussion of the Issues" that contaimed the stateinent that the House Report on the House bill was "incorporated by reference into the legislative history of the present bill."96 That statement inust be read with caution, however, because the House bill did not become law; any conflicts in interpretation should be resolved by a comparison of the Senate's "Description of Major Issues"97 and the House's "Discussion of the Issues."98 The Sen-

88. See S. 755, 96th Cong., 1st Sess., 125 Cong. REC. S3338 (daily ed. Mar. 26, 1979).

89. The session also produced a comprehensive study of federal regulation. See SENate Comm. on Government Operations, Study on Federal Regulation, 95th Cong., 1st Sess. (1977).

90. To illustrate the popularity of small business in Congress, there has not been a single negative vote cast against any regulatory flexibility bill, in subcommittee, in full committee or on the floor, since the first bill was introduced in 1977. See 126 CoNG. REC. H8470 (daily ed. Sept. 8, 1980).

91. S. 299 , supra note 83 , and H.R. 4660 .

92. H.R. 4660 did, however, borrow the definitions of "agency" and "rule" from the APA. 5 U.S.C. § 551(1)(4) (1976).

93. See note 86 supra.

94. 126 CoNG. REC. H8548 (daily ed. Sept. 8, 1980).

95. See id. H8468-80. The Senate description and analysis is set forth at 126 CoNG. REc. S10,934-43 (daily ed. Aug. 6, 1980).

96. Id. H8468.

97. See 126 Cong. Rec. S10,934-43 (daily ed. Aug. 6, 1980). 
ate bill had reached the floor of the Senate on August 6, 1980, and had been presented by Senator Byrd of West Virginia in the form of a substitute amendment ${ }^{99}$ whose principal purpose was to recodify the bill from sections 551 and 553 of title 5 to a new chapter (sections 601612). ${ }^{100}$ It passed the Senate in that form on the same day. ${ }^{101}$ The President signed the bill into law on Septeinber 19, 1980.

\section{B. Overview of the RFA.}

The RFA proceeds from an optimistic assumption: highlighting the problems of small business and offering suggestions will allow agencies to solve problems they have largely created, thus obviating any need to deregulate small business through outright statutory exemptions. This process of self reform assumes a receptive bureaucracy. ${ }^{102}$

The RFA's structural limitations are crucial. It applies only to the substantive rulemaking process under the informal rulemaking provisions of the APA and of related organic legislation. ${ }^{103}$ Thus, by its terms, the RFA does not apply to the vast amount of administrative activity that is not rulemaking, whether it be adjudication or the virtually unlimited realm of informal action. ${ }^{104}$ Moreover, it does not even reach rulemaking that is not subject to notice and comment. ${ }^{105}$ Therefore, the RFA does not address many of the problems small business faces with agencies such as the IRS that operate niore through report-

98. See 126 ConG. REC. H8468-70 (daily ed. Sept. 8, 1980).

99. See 126 CoNG. REC. S10,931 (daily ed. Aug. 6, 1980). To the extent the unprinted amendment varied from S. 299, the Senate "Description of Major Issues" accompanying the ainendment may be a better source of congressional intent than the Senate report accompanying the original S. 299.

100. Id. $\mathrm{S} 10,930-31$.

101. Id. $\mathrm{S} 10,944$.

102. It is not entirely fair to evaluate agency performance historically. With increasing frequency agencies have developed techniques for responding to the special problems of small business. See text accompanying notes 71-78 supra. Moreover, the appointment process puts persons into leadership positions whose outlooks are undoubtedly more receptive to small business problems.

103. The RFA defines "rule" to include "any rule for which the agency publishes a general notice of proposed rulemaking pursuant to section 553(b) of this title, or any other law." 15 U.S.C. §601(2) (Supp. IV 1980). For a discussion of these provisions, see text accompanying notes $155-69$ infra.

104. Although precise figures are impossible to obtain, estimates suggest that about $90 \%$ of government action is informal. See Verkuil, A Study of Informal Adjudication Procedures, 43 U. CHI. L. Rev. 739, 741 (1976).

105. Some examples of this type of rulemaking are interpretative rules, and other rules exempted from 5 U.S.C. $§ 553$ (b) (1976). Also, rules of "particular applicability" such as ratemaking are excluded. 5 U.S.C. $\S 601(2)$ (Supp. IV 1980). 
ing requirements, individual actions, and interpretative rules than through substantive rules.

The RFA does not mandate any particular outcoine in rulemaking. It requires consideration of alternatives that are less burdensoine to small business, but it only requires that agencies explain why those alternatives were rejected. ${ }^{106}$ The RFA extends this process to agency evaluation of existing rules over a ten-year period. ${ }^{107}$ Although it gives the courts and the Chief Counsel for Advocacy some limited responsibilities, ${ }^{108}$ it provides few express enforcement powers.

The Office of Advocacy of the SBA is to administer and to implement the RFA. This is a natural place to lodge oversight responsibility from the point of view of the small business community, for that community looks on the Chief Counsel's office as a safe harbor in the unfriendly world of regulation. Difficulties with the role of the Office of Advocacy under the RFA do exist, however. The Office is clearly small business and not small entity oriented. Thus, to the extent small organizations and small governmental jurisdictions seek a supportive advocate, they may not find one in the Chief Counsel. ${ }^{109}$ Moreover, the Office of Advocacy may be hard pressed to provide the kind of professional guidance to agencies that more established oversight agencies like the OMB could provide.

The RFA adds certain steps to the typical rulemaking process. Ruleınaking under APA section 553 involves four distinct steps: (1) publication of the proposed rule in the Federal Register; (2) receipt of written and oral comments from the public; (3) possible modification

106. The note following section 601 of the RFA states:

(b) It is the purpose of this Act ... to establish as a principle of regulatory issuance that agencies shall endeavor, consistent with the objectives of the rule and of applicable statutes, to fit regulatory and informational requirements to the scale of the businesses, organizations, and governmental jurisdictions subject to regulation. To achieve this principle, agencies are required to solicit and consider flexible regulatory proposals and to explain the rationale for their actions to assure that such proposals are given serious consideration.

5 U.S.C. $\$ 601$ app. at 124 (Supp. IV 1980).

Section 603 requires consideration of at least four alternatives: (1) tiering; (2) clarification, consolidation, or simplification; (3) performance rather than design standards; and (4) exemptions. Id. 603(c).

107. Id $\S 610$. The ten-year period may be extended, on notice, in annual increments for up to an additional five years. $I d$.

108. The Office of Advocacy's best enforcement weapons are publicity through its annual reports on agency compliance to the President and to Congress, id. § 612(a), and through amicus appearances in court when the rule is under review. Id. $\$ 612(\mathrm{~b})$. The role of the courts on review is very limited. See notes $270-83$ infra and accompanying text.

109. The Office of Advocacy responds to its small business constituency as required by its unandate. Other small entities either do not have equivalent advocates in government or if they do -education, for example - they are located in other agencies. 
of the proposed rule in light of the comments; and (4) publication of the final rule in the Federal Register with a statement of basis and purpose. ${ }^{110}$ Under the RFA the following additional steps must be taken: before a proposed rule is published, the agency must prepare an Initial Regulatory Flexibility Analysis (IRFA), which it publishes along with the proposed rule, ${ }^{111}$ unless it certifies in the Federal Register that the rule will not "have a significant economic impact upon a substantial number of small entities;" 112 the IRFA or the certification must be sent to the Chief Counsel for Advocacy, pubhished in the Federal Register, and actual notice must be sent to affected small entities; ${ }^{113}$ during the comment period, the agency should hold conferences and public hearings on the rule as it affects small entities; ${ }^{114}$ and, after the comment period, the agency must prepare a Final Regulatory Flexibility Analysis (FRFA) along with its final rule and statement of basis and purpose (unless it has made a certification as noted above). The agency also lias contmuing responsibilities to review the rules periodically and to publish biannual regulatory agendas. ${ }^{115}$

\section{Analysis and Critique of Prvotal Provisions}

Though numerous questions arise under the RFA, ${ }^{116}$ they cluster around several broad imquiries: Who does the RFA cover (or what is the meaning of "small entities")? Which agencies and rules are within its scope? How is the certification process to be administered? What does the regulatory-flexibility process demand? What does the agency rule-review process contemplate? What is the role of the courts on review; and what is the role of the Office of Advocacy? This article will consider each of these imquiries im turn.

110. See 5 U.S.C. \& 553 (1976).

111. Id. $\$$ 603(a) (Supp. IV 1980).

112. Id. $\S 605(\mathrm{~b})$.

113. Id. $\S 609(3)$.

114. Id. $\S 609(4)$.

115. The RFA requires that agencies publish in the Federal Register a plan for a review of their rules within ten years. Id. 610(a). Additionally, agencies inust publish annually a list of rules that significantly affect small entities and that will be reviewed during the succeeding year. $I d . \S 610(c)$. This latter requirement may be viewed as an additional procedure imposed on section 553 rulemaking.

116. Milton Stewart, the first Chief Counsel for Advocacy, has published a useful introduction to the RFA that answers some preliminary questions. Stewart, The New Regulatory Flexibility $A c t, 67$ A.B.A.J. 66 (1981). The recently confirmed Chief Counsel, Frank Swaim, is a former counsel to the National Federation of Independent Business, and like Mr. Stewart, was active in the legislative efforts that produced the RFA. 


\section{A. The Definitional Components of "Small Entities."}

The RFA is law because of the support it received from small business, whose needs are its obvious focus. Yet its definitional section subsumes small business within the term "small entity," a term that also includes "small organizations" and "sinall governmental jurisdictions." 117 These latter two terms greatly expand the potential coverage of the RFA, but they also introduce substantial definitional difficulties.

The term "sinall business" has generally accepted meanings, established by the SBA; the RFA incorporates those meanings by reference. Moreover, the RFA requires any agency that seeks to alter the established definition of "sinall business" first to consult with the Office of Advocacy and to allow an opportunity for public comment. ${ }^{118}$ Because the estabhished definition of sinall business relates to loan and procureinent functions, ${ }^{119}$ there may be a tendency for agencies to seek new definitions for RFA purposes. While this inay complicate the task of the Office of Advocacy, ${ }^{120}$ careful consultation between agencies and the Office of Advocacy can produce more useful definitions. ${ }^{121}$

The two otler definitional categories - small organizations and sinall governmental entities - are not familiar to agencies and the Office of Advocacy does not have the same consultative role with respect to their formulation. Thus, problens of coverage will undoubtedly einerge as individual agencies attempt to define these terms.

1. The Meaning of "Small Organizations." Section 601(4) of the RFA provides:

[T] he term "small organization" means any not-for-profit enterprise which is independently owned and operated and is not dominant in its field, unless an agency establishes, after opportunity for public comment, one or more definitions of such term which are appropriate to the activities of the agency and publishes such definition(s) ni the Federal Register . . . . .122

117. 5 U.S.C. $\S 601(3)-(6)$ (Supp. IV 1980).

118. $I d . \S 601(3)$.

119. See note 39 supra.

120. The former Chief Counsel indicated a preference to retain established meanings of "small business." See Stewart, supra note 116, at 67.

121. The SEC provides a good example of successfully creating new definitions of "small business" and "small organization" as applied to securities issuers and registrauts of securities exchanges. See Notice of Proposed Rulemaking, 46 Fed. Reg. 19,251 (1981). The SEC had a productive exchange of views with the Office of Advocacy concerning the new definitions. See Letter froin A. J. Prendergast, Acting Chief Counsel for Advocacy, to George Fitzsimmons, Secretary of the SEC (May 27, 1981). The SEC also requested public comments on whether its rules would have a "significant economic impact upon a substantial number of small entities." 46 Fed. Reg. 19,251 (1981).

122. 15 U.S.C. § 601(4) (Supp. IV 1980). 
(a) Legislative guidance. The "Description of Major Issues" and the section-by-section analysis that accompanied the Senate discussion on the RFA ${ }^{123}$ (and which the House imcorporated by reference) ${ }^{124}$ discuss the small organization concept and take the general approach that an agency applying them is to be "guided by the same considerations which were used in developing the definition of small busmess." 125 The Senate analysis lists three such considerations: a business must be (1) independently owned and operated; (2) not dominant in its field; and (3) must fall within the SBA size standards. ${ }^{126}$ The last consideration is applicable to small organizations only by analogy. ${ }^{127}$

There are only a few potential small organizations actually named in the Senate analysis. It lists the YMCA/YWCA and the Boy Scouts/Girl Scouts simply to imdicate that their nationwide status does not automatically disqualify them as small organizations ${ }^{128}$ on the ground that they are dominant in their field. ${ }^{129}$ The House did not discuss any exainples in its section-by-section analysis of its bill; furthermore, the House bill's definition of "small organization" varies from that which became law: it included "unincorporated businesses" and "sheltered workshops" as well as non-dominant, independent, nonprofit enterprises. ${ }^{130}$ One must question whether the House defini-

123. 126 CONG. REC. $\$ 10,934-43$ (daily ed. Aug. 6, 1980).

124. See 126 CoNG. REC. H8468 (daily ed. Sept. 8, (1980)). See notes $96-97$ supra and accompanying text.

125. 126 CoNG. REC. S10,940 (daily ed. Aug. 6, 1980).

126. Id.

127. SBA size standards concerning number of employees (under 500) or dollar umount of sales (under $\$ 5,000,000$ ) may or may not be useful standards in nonprofit organizations.

128. 126 CONG. REC. S10,940 (daily ed. Aug. 6, 1980). The section-by-section analysis indicates that these organizations should be tested by other criteria such as structure and operating characteristics at the local level, organizational resources, and ability to comply with rules and reporting requirements. This latter characteristic seems to confuse definitional problems with substantive ones, and serves to highlight the difficulties agencies will face in applying the small organization standard.

129. "Dominance" is to be given a "liberal" interpretation so as not to disqualify nonprofit organizations. Id.

130. See H.R. 4660, § 210(2), discussed in H.R. REP. No. 519, 96th Cong., 1st Sess. 29-30 (1979). An earlier draft of S. 299 contained definitional terms similar to those in H.R. 4660 . See S. 299, 96th Cong., 1st Sess., 125 CoNG. REc. S907 (daily ed. Jan. 31, 1979). This language also appeared in earlier bills. See S. 3330, 95th Cong., 2d Sess., 124 CoNG. REc. S11,499 (daily ed. July 21, 1978); S. 1974, 95th Cong., 2d Sess., 123 CoNG. Rec. 25,844 (1977). The Senate Judiciary Committee eliminated those terms from S. 299 when its Committee reported the Bill on May 5 , 1980. This may turn out to be a distinction without a difference in practice, however, because unincorporated businesses are likely to be picked up in the definition of small business, and sheltered workshops may simply be included within the overall definition of small organization. Given the generous nature of the definition section, there apparently is no intent to exclude these two types of organizations from coverage under the RFA. 
tions can be used in the unlikely event of definitional conflicts.

Further examples of what Congress intended "small organizations" to mclude are hard to find in the legislative hearings. The only category of small organizations that is inentioned is that of colleges and universities. In the hearings on S. 1974, the predecessor to the bill enacted, Thomas O. James, a representative of the National Association of College and University Business Officers, testified about the need small colleges - defined as having approximately 2,000 students and annual budgets of under $\$ 15$ million - had for relief from federal regulations. ${ }^{131}$ After his prepared statement, James had the following inconclusive exchange with Senator Culver, the chief sponsor of the Senate bill:

SENATOR CULVER. As you read them, Dr. James, do you think that the definitions in the bill of a small business and a small organization include small universities?

DR. JAMES. Yes, I do. ${ }^{132}$

In the hearings on S. 299, Sheldon Stembach, General Counsel of the American Council on Education, submitted a written statement that supported the bill but that also urged that the bill "be amended to include colleges and universities."133 The bill became law without the ainendinent. Thus, it is not obvious that colleges and universities are within the definition of sinall organizations or, if they are, whether only soine of them are "small" under the above standards. On the other hand, given the paucity of discussion about the tern "small organizations," colleges and universities, like other possible candidates for coverage (nuseums, charities, foundations, and the like) should be free to make arguments derived from the definition of "small organization." In addition, colleges and universities can argue that coverage is consistent with the RFA's apparent purpose of including small concerns that fall outside the definition of small business. ${ }^{134}$

(b) The problems of applying the definition of colleges and universities. Despite some question about the meaning of the terin "small organization," there will undoubtedly be assertions that it applies to colleges and universities. ${ }^{135}$ Problems with n1any kinds of regulations

131. 1977 Senate RFA Hearings, supra note 16, at 46 (statement of Thomas O. James).

132. Id. 49. Notice that $\mathrm{S}$. 1974 contained a definition of sinall organization that was different from that which ultimately energed from S. 299. See note 130 supra and accompanying text.

133. Letter from S. Steinbach, American Council on Education, to Senator Culver, (Sept. 24, 1979), reprinted in Regulatory Reform: Hearings on S. 104, S. 262, S. 299, S. 755 and S. 1291 Before the Subcomm. on Administrative Practice \& Procedure of the Senate Comm. on the Judiciary, 96th Cong., 1st Sess., pt. 3, at 212-13 (1979) [hereinafter cited as 1979 Senate RFA Hearings].

134. See text accoinpanying notes 123-26 supra.

135. Sheldon Steinbach, General Counsel of the American Council on Education, mailed a memorandun on November 5, 1980 to college and university presidents that asserted that all 
im recent years have made the educational sector a strong ally of regulatory restraint. ${ }^{136}$ The Department of Education has published its definition of those colleges and universities that fall under the RFA. ${ }^{137}$ This definition is relevant in all proceedings before that agency and will presumably influence other agencies. The definition, whicls severely circumscribes the meaning of "small organization," serves to highlight soine of the problems the educational establishment will face in arguing for coverage under the RFA.

The Department's definition of "sinall institution of higher education" includes all accredited colleges, public and private, that have a full-time equivalent student enrollment of fewer than 500 or an overall student population of fewer than 550.138 This very narrow definition includes only twenty to twenty-five percent of all higher educational institutions and affects less than $2.5 \%$ of all students in higher education. Based on students affected, the definition creates a virtually de minimis category. ${ }^{139}$

The main problein with the small organization definition is that it does not appropriately categorize colleges, universities, and nonprofit institutions. For exaunple, the language borrowed from the small business definition - "not dominant im its field" - makes the small organization definition difficult to apply. The question immediately arises whether any college or university is dominant in its field. Certainly soine are prestigious and others are relatively large, but none would seem to qualify as dominant in the business or antitrust sense. Unlike

independent and public colleges and universities are covered by the RFA (memoranduni on file with Duke Law Library.)

136. The latest record-keeping and reporting requirements imposed by government agencies have been particularly burdensoine for higher education. Problems include OSHA handicap-access regulations and ERISA pension regulations. See Steinbaclt letter, supra note 133. Perlaps no regulation las caused more consternation than OMB's Regulation A-21, whicl requires each faculty nember's professional time to be accounted for and recorded on a periodic basis. See 44 Fed. Reg. 12,368 (1979) (revision of Federal Management Circular 73-8).

137. 46 Fed. Reg. 3920 (1981).

138. Id. at 3920 (1981). The Department circulated the proposed definition for public comunent as required by the RFA. Although the comment period expired in February 1981, the definition lias uot yet been revised or promulgated. Recently the Department certified that small colleges and universities would not be significantly affected by a proposed rule that clianged the reporting requireunents for Natioual Defense Student Loans. 47 Fed. Reg. 908,910 (1982). The Departinent inade no reference to its proposed size standards.

139. Comments received by the Department of Education on its proposed size standards have criticized its approacli. See, e.g., Letter froun Christine Milliken, General Counsel, National Association of Independent Colleges and Umiversities (Feb. 17, 1981); Letter from Sheldon Stembacl, General Counsel, American Council on Education (Feb. 17, 1981) (stressing that the narrowness of the standard defeats the purpose of the statute). Other commentators liave argued for including all higher educational institutions within the definition. See Letter from Clauston Jenkins, Executive Assistant, North Carolina State University to U.S.D.E. (Feb. 9, 1981). 
businesses, prestigious colleges and universities do not expand capacity to assert their dominance and to drive other institutions out of the market. 140 Thus, the dominance question is more appropriately resolved along the lines suggested in the Senate section-by-section analysis for other national nonprofit organizations. ${ }^{141}$

On the other hand, there are significant differences in size annong colleges and universities. For example, one can draw distinctions based on asset or endowment size. ${ }^{142}$ The assumption would be that those institutions with large endowments have more resources to comply with the regulations, an argument familiar to small business. ${ }^{143}$ if one adds public institutions to this list on the ground that state funding guarantees their endowments, one can draw several significant definitional lines. If colleges and universities as a group are suffering froin disproportionate regulatory burdens, however, then including all of them in the definition of sinall organization would better carry out the purpose of the RFA.

This discussion raises two points. First, when an individual agency decides to define "sinall organization," it should not necessarily use a dominance test. 144 Second, the definition is only for purposes of determining jurisdiction under the RFA. Although deemed to be within the RFA definition of a small organization a college might still be exempted when the agency promulgates any resulting rules. Tiering concepts, for example, may usefully discriminate between large, well-

140. Prestigious private universities have a national dominance in the sense that students prefer them to other schools. But their prestige is measured more by the number of students they reject than by the number they accept. Although such universities experience some growth over time, they clearly do not grow to meet demand. State universities are somewhat different. In the last twenty years, there has been enormous growth in public-sector higher education because of unmet demand for higher education. With but a few important exceptions, public universities do not have national dominance, and even those that could rival the private universities are restrictcd by residency requirements. Thus unless one were to define states as sub-markets for educationaldominance purposes, it would be difficult to label public institutions as dominant.

141. See notes 128-29 supra and accompanying text.

142. Information on endowment size is readily available for the educational sector and the foundation sector. See, e.g., Information Please Almanac 709 (1982). By this measure, there are some clearly "dominant" institutions.

143. One cannot ignore that some institutions are better situated to comply with federal regulations than others. Concerning competition for federal grants and contracts, for example, those institutions that have achieved some economies of scale (because of research-grant size) have established offices funded by overhead charges that can produce the reports and records necessary to obtain and retain lucrative funding. In this sense, "research universities" as a catcgory may be distinct from colleges whose primary role is teaching.

144. 15 U.S.C. 8 601(4) (Supp. IV 1980) introduces two stages: (1) a definition of small organization that controls unless (2) an agency after public cominent estabhshes and publishes definitions appropriate to the activities of the agency. There is nothing in the RFA or its legislative history that limits the second stage to the standards contained in the first. 
endowed universities and small tuition-dependent colleges for purposes of particular regulations. The relevance of size standards changes according to the substantive goal of the regulation. ${ }^{145}$ The purpose of the RFA is to aid as many small entities as possible by reducing the burdens of regulation. Definitions that mclude more entities at the outset and thereby allow agencies to address particular problems of the entities within the regulatory-flexibility context are much more likely to ineet the RFA's corrective purpose.

2. The Meaning of "Small Governmental Jurisdiction." Section 601(5) of the RFA states:

[T] he term "small governmental jurisdiction" means governments of cities, counties, towns, townships, villages, school districts, or special districts, with a population of less than fifty thousand, unless an agency cstablishes, after opportunity for public comment, one or more definitions of such term which are appropriate to the activities of the agency and which are based on such factors as location in rural or sparsely populated areas or limited revenues due to the population of such jurisdiction, and publishes such definition(s) in the Federal Register . . . ${ }^{146}$

This definition is inore precise than the definition of "small organization" and should not create as inany mterpretative difficulties. ${ }^{147}$ It naines the entities covered and estabhishes an objective population size limit of 50,000 . Should an agency choose, after public comment, to establish its own definition, it is constrained by the explicit factors mentioned above. ${ }^{148}$ The legislative background to this definition is less extensive than the legislative history of the term "small organization," but it does reveal one important change. The definition did not appear in the original Senate bill introduced by Senator Culver in August $1977,{ }^{149}$ but appeared later with the threshold population initially set at

145. Some universities are better able to comply with reporting and record-keeping requirements than others. Size of student body, size of faculty, and annual budget should all be factors in deciding whether to tier the requirements of the rule. The rule itself will suggest when this is appropriate. If the rule involves reporting requirements concerning governinent grants and contracts, for example, the amount awarded per college or university is a relevant basis for differentiation.

146. 15 U.S.C. $\$ 601(5)$ (Supp. IV 1980).

147. One comphication may occur if public universities and colleges (failing to qualify under the "small organizations" standard because they are unincorporated, nonprofit institutions) instead seek to be included in the definition of "small governinental jurisdiction." The latter definition does not discuss higher educational institutions, but an agency may be able to include thein as part of a separate definitional scheme.

148. Finding the RFA definition of small governmental jurisdictions inappropriate, the Department of Education undertook to define small local educational agencies in a manner that would "better carry out the intent of the Act." 46 Fed. Reg. 3920, 3921 (1981). Its definition, based on number of students (fewer than 1,500), has not been adopted.

149. See S. 1974, 95th Cong., Ist Sess., 123 CoNG. REC. 25,844 (1977). 
$100,000.150$ There was no discussion in the Senate of the change of the threshold population level from 100,000 to $50,000.151$ One might infer from this change that Congress sought to limit the nuinber of governmental jurisdictions that could take advantage of the RFA.

Population size will not always be a critical variable, however, and even when it is, the Senate section-by-section analysis seems to reduce its impact. The analysis states: "Definitions established by an agency need not adhere strictly to the 50,000 population standards nor are they restricted to the types of requirements the agency may impose under a rule affecting governmental jurisdictions." 152 This explanation appears to give some freedom to agencies to include governmental jurisdictions with populations above the 50,000 level as small entities. The implication of the legislative history is, however, to exclude such jurisdictions if they approach a population of 100,000.

\section{B. Agencies and Rules Covered by the RFA.}

The RFA borrows the APA's definition of "agency"153 and, like the APA, casts a wide net over virtually all government agencies. Even the SBA is within the jurisdiction of the RFA. The ultimate question of coverage under the RFA, however, is whether the rules promulgated by the agency are within the scope of the RFA, ${ }^{154}$ not whether the agency itself is subject to the Act. Much debate can be expected on this question.

Some agencies will consider themselves exempt from the RFA's coverage because they do not promulgate rules pursuant to section 553 of the APA "or any other law."155 Problems arise when agencies, the

150. S. 3330 , 95 th Cong., 2 d Sess. $\S 3$ (g)(4)(A), 124 CoNG. REC. S11,499 (daily ed. July 21 , 1978). This definition was added to $S .1974$ when it passed the Senate on October 14, 1978. See text accompanying note 82 supra. When S. 299 was introduced, it contained the same definition as that in S. 1974. See S. 299, 96th Cong., Ist Sess., 125 ConG. REC. S907 (daily ed. Jan. 31, 1979).

151. The 100,000 popnlation threshhold was still in S. 299 when it was reported by the Senate Judiciary Committee on May 5, 1980. See S. REP. No. 878, 96th Cong., 2d Sess. 14 (1980). The population level was changed to 50,000 only in Senate Unprinted Amendment No. 1502, see 126 CONG. REC. S10,931-33 (daily ed. Aug. 6, 1980), which served as a substitute for S. 299 and passed the Senate on August 6, 1980. Id. S10,944.

152. 126 Cong. ReC. S10,934, S10,940 (daily ed. Aug. 6, 1980).

153. See 5 U.S.C. $\$$ 601(1) (Supp. IV. 1980) ("the ternn 'agency' means an agency as defined in Section 551(1) of this title").

154. Thus, during the legislative hearings, some of those agencies that did not promulgate rules pursuant to section 553 of the APA, such as the Central Intelligence Agency, took no interest in the RFA. See Letter of Stansfield Tnrner to Senator Eastland (Jan. 19, 1978), reprinted in The Regulatory Flexibility Act: Joint Hearings on S. 1974 and S. 3330 Before the Subcomm. on Administrative Practice and Procedure, Senate Comm. on the Judiciary and Senate Select Comm. on Small Business, 95th Cong., 2d Sess., pt. 2, at 294 (1978).

155. 5 U.S.C. $\$ 601(2)$ (Supp. IV 1980). 
public, or the Office of Advocacy disagrees about whether some agencies must comply with section 553 or whether such "other law" (including perhaps procedural regulations) exists.

1. What is a Section 553 Rule? Section 553(a) of the APA exeinpts military or foreign-affairs functions from its rulemaking notice and comment requirements. ${ }^{156}$ This exemption suggests that the Department of Defense and the State Department are excluded from the RFA's coverage, unless those agencies have orgamic legislation that require particular rules to be published for comment. APA rulemaking requirements also do not apply to agency rules on matters relating to agency management and personnel or to public property, loans, grants, benefits or contracts. ${ }^{157}$ The RFA modifies this exemption by its definition of "rule," which specifically includes federal grants to state and local governments for which the agency provides opportunity for public comment. 158

Section 553 of the APA contains other exemptions from its notice and comment requirenents that should cause even greater consternation. Interpretative and related kinds of rules are exempted from the notice and comment requirenent as are rules the agency exempts for good cause. ${ }^{159}$ Concerning the former exemption, there may be some rules that an agency can validly exempt from notice and RFA requirements if they are clearly of the policy-oriented, imterpretative variety. The RFA was, after all, designed to cover substantive rules that affect small entities. But frequently it is difficult to determine whether an interpretative rule is substantive im effect. ${ }^{160}$ Subsequently, an agency

156. Id. $\S 553(\mathrm{a})(1)(1976)$

157. Id. $\S 553(\mathrm{a})(2)$.

158. Id $\S 601$ (2) (Supp. IV 1980). This modification is difficult to justify; it partially reiterates the exemptions of the APA that the American Bar Association and the Administrative Conference of the Umited States are on record as opposing. See 3 Administrative Conference of THE UNITEd States, 3 ReCOMmendations AND Reports 53 (Jan. 1, 1973 - June 30, 1974) (resolution no. 2). Agencies that have voluntarily assumed notice and comment obligations in these situations alleviate the problem to some extent. These agencies may balk, however, at voluntarily assuming the additional responsibilities imposed by the RFA; there is some question whether they are bound to assume those responsibilities. See notes $164-65$ infra.

159. 5 U.S.C. § 553(b) (1976) provides in part:

Except when notice or hearing is required by statute, this subsection does not apply -

(A) to interpretative rules, general statements of policy, or rules of agency organization, procedure, or practice; or

(B) when the agency for good cause finds (and mcorporates the finding and a brief statement of reasons therefor in the rules issued) that notice and public procedure thereon are impracticable, unnecessary, or contrary to the public interest.

160. See Asimow, Public Participation in the Adoption of Interpretive Rules and Policy Statements, 75 MrCH. L. REv. 521, 545-53 (1977). Of particular concern to the intended beneficiaries of the RFA is the fact that the Treasury Department considers most IRS regulations to be of the interpretative variety. 
may have problems ascertaining (when it establishes its regulatory agenda, for example) whether a particular rule is subject to the RFA.

The drafters of the RFA apparently did not fully contemplate the use of the good-cause exception to notice and coininent procedures, a loophole that has fallen into disfavor in recent years witl Congress and commentators. ${ }^{161}$ Congress surely would not have provided agencies with such a convement escape from regulatory-flexibility analyses; therefore, any agency that uses the good-cause exception for that purpose should be closely scrutinized by the SBA's Office of Advocacy. Agencies at the edge of compliance, whether because of the interpretative rule or good-cause exceptions, should be wary of opting out of the RFA process.

2. The Meaning of "Other Law." Two problems arise when defining "other law." The first is wlether "other law" includes agency regulations as well as legislation. ${ }^{162}$ Neither the RFA nor its legislative history answer this question; instead, one must seek guidance from related areas of administrative law. In many other situations regulations are regarded as law. ${ }^{163}$ Such examples may be less persuasive in this context since Congress could have been unore precise in the wording of the RFA. Nevertheless, agencies which voluntarily impose notice and comment requirements on themselves by regulation ${ }^{164}$ sliould be subject to RFA requirements although they would not have been subject to these requirements had tliey not promulgated such procedural regulations. ${ }^{165}$ Each agency so situated can certainly abrogate its RFA responsibilities by revoking its procedural regulations. As a practical policy matter, however, that inay be difficult to do. Moreover, in many situations the reasons that lead an agency to adopt notice and comment procedures by regulation apply equally to the performance of regulatory-flexibility analyses.

161. Several recent statutes have narrowed the applicability of the exemptions. See, e.g., The Federal Hazardous Substances Act, 15 U.S.C. \& 1262(e)(1) (1976); Poison Prevention Packaging Act, 15 U.S.C. \& 1474(a) (1976). Professor Davis has recommended that this exemption be narrowed or eliminated. See K. Davis, Administrative Law Text 6.01 (1972).

162. See note 158 supra and accompanying text.

163. See B. Schwartz, Administrative LaW 59 (1976). Professor Schwartz cites regulations regarding river navigation, air traffic control, ICC safety rules and fish and game rules as examples of regulations that are routimely enforced in the same manner as statutes. Id. 157-60.

164. The Department of Health, Education and Welfare (HEW) (the predecessor of the Department of Health and Hunnan Services), for example, voluntarily submitted its rulennaking to the notice and comment provisions of section 553. See 36 Fed. Reg. 2532 (1971).

165. See National Welfare Rights Org. v. Mathews, 533 F.2d 637, 648 (D.C. Cir. 1976). The N.W.R.O. court remanded a rule, which was subject to HEW's voluntary acceptance of notice and commeut requireınents, for failure to provide adequate factual findings. Had HEW not voluntarily undertaken to provide notice and comment, its rule presumably would not have received less scrutiny. 
The "other law" problem is also raised when Congress imposes notice and comment responsibilities by statute on an agency that is otherwise free from the requirements of section 553 of the APA. One such agency is the Office of Federal Procurement Pohcy (OFPP), which supervises government contracts. Ordinarily government contracts are exeinpt from the notice and comment provisions of section 553 but the Administrator of the OFPP is required by statute to establish "criteria and procedures for an effective and timely method of soliciting the viewpoints of interested parties to comment."166 The Administrator promulgated procedural regulations under this provision that provide for notice of rulemaking and an opportunity to comment. ${ }^{167}$ Thus, both the statute and the regulations would seem to be "other law" for RFA section 601 purposes.

To some extent this automatic application of the RFA to procurement regulations may coine as a surprise to Congress and to the Executive branch because they have long wanted to keep the governmentcontracting process free from extensive procedural entanglements. In fact, for this reason (among others) Congress did not inake the provisions of section 553 of the APA directly applicable to procurement regulations ${ }^{168}$ and the Carter administration excluded the OFPP from Executive Order 12,044. ${ }^{169}$ Nevertheless, the definition of "rule" in section 601 of the RFA does not allow for individualized exceptions based on the "other law" requirement. It is likely that other agencies will also find themselves caught by the RFA in this fashion.

\section{The Certification Process.}

The RFA contains an escape clause so that even if it applies to the particular agency in question the regulatory-flexibility analysis still may not be required. Section 605(b) provides:

Sections 603 and 604 of this title shall not apply to any proposed or final rule if the head of the agency certifies that the rule will not, if promulgated, have a significant economic impact on a substantial

166. 41 U.S.C. § 405(d)(3) (Supp. III 1979).

I67. See 41 Fed. Reg. 34,324 (1976).

168. The legislative history of the statute that created the OFPP indicates a concern that notice and comment procedures be "effective and timely." Congress therefore left it to the administrator to evaluate the "benefits and burdens of notice and commeut rulemaking." See H.R. REP. No. 1176 , 93d Cong., 2d Sess. 15 (1979). Once OFPP promulgated procedural regulations it presumably decided that the benefits of notice and comment procedures outweighed the burdens, but it did not do so in light of the RFA.

169. See 43 Fed. Reg. 12,665 (1978). The extension of the Executive Order to OFPP was thought unnecessary, because the Office had issued procedural regulations. The Reagan administration's Executive Order No. 12,291, 46 Fed. Reg. 13,193, reprinted in 5 U.S.C. app., $§ 601$, at 124 (Supp. IV 1980), contains no such exemption. 
number of small entities. If the head of the agency makes a certification under the preceding sentence, the agency shall publish such certification in the Federal Register, at the time of publication of general notice of proposed rulemaking for the rule or at the time of pubhication of the final rule, along with a succinct statement explaining the reasons for such certification, and provide such certification and statement to the Chief Counsel for Advocacy of the Small Business Administration. ${ }^{170}$

Sections 603 and 604 prescribe the initial and final regulatory-flexibility analyses that are the chief tools of the RFA. Because agencies will undoubtedly try to avoid compliance with sections 603 and 604 by invokimg section 605(b), the latter section is bound to be the source of inuch controversy.

The meaning of "signiflcant economic inupact upon a substantial number of small entities" is crucial to the RFA's inuplementation. Indeed, unless the phrase is satisfactorily defined the RFA will be a nulhity. ${ }^{171}$ That the words "significant" and "substantial" were both used provokes the question whether a different meaning is inuplied by the choice of two words that are otherwise synonymous. For the RFA to operate effectively, considerable attention must be given to the meaning of these terms.

1. Legislative Background to the Certification Process. There is hittle discussion of the phrase "significant econounic inupact on a substantial number of small entities" in the earher legislative reports, but the phrase did receive attention from the Senate and the House in the reports accompanying S. 299.172 The Senate stated that any atteinpt to define the term "significant econornic inupact" more precisely might be "counterproductive"; 173 it also emphasized that in deciding what the

170. 5 U.S.C. $\S 605(b)$ (Supp. IV 1980).

171. To date, most agencies appear to utilize the certification process for the vast majority of RFA dispositions. In the period July 1, 1981 to October 1, 1981, the Office of Advocacy logged 489 RFA dispositions; 412 were certifications, 19 wcre IRFA's, 18 were periodic (six month) reviews. The remainder were statements that the RFA did not apply at all. Statement of Frank S. Swaim, Chief Counsel for Advocacy of the SBA, before the Subcomm. on Export Opportunities and Sinall Bnsiness Problems of the House Comm. on Small Business (Oct. 7, 1981) at 16.

172. The phrase appeared in S. 299 as it was reported by the Senate Judiciary Committee on May 5, 1980. See S. 299, 96th Cong., 1st Sess., 126 Cong. Rec. S10,931 (daily ed. Aug. 6, 1980). Eartier Senate and House bills also contained this wording. See S. 1974, 95th Cong., 1st Sess. $\S 3(5), 123$ CoNG. Rec. 25,844 (1977); H.R. 7739, 95th Cong., 1st Sess. § 4, 123 CoNG. REC. 18,620 (1977); H.R. 4660, 96th Cong., 1st Sess. § 207(b) 125 CoNG. REC. H5420 (daily ed. Jan. 28, 1979). With slightly different phraseology, this wording appeared in the Senate ommibus regulatory reform bill, S. 2147, 96th Cong., 1st Sess. § 634, 125 CoNG. Rec. S19,039 (daily ed. Dec. 18, 1979). The omnibus reform bill stipulated that no regulatory flexibility analyses would be required if the agency determined that "the rule will not, if implemented, have an adverse effect on a substantial number" of small entities. Id.

173: 126 CoNG. REC. S10,943 (daily ed. Aug. 6, 1980) (section-by-section analysis). 
term "substantial number" meant, the agencies should consider the total number of firms affected, not the percentage of affected firms in the industry. 174

The House, devoting a substantial portion of its three-page discussion of the issues to definitional problems, ${ }^{175}$ stated that "the term 'significant economic impact' is neutral with respect to whether such impact is beneficial or adverse."176 Thus, a rule's potential benefit to small entities does not discharge an agency from the regulatory-flexibility process smce the agency does even more for them. The House discussion also addressed the question of what constitutes a "substantial number of small entities," concluding that "clearly, any anticipated rulemaking which common sense would suggest could have a direct, noticeable impact on several thousand or more small entities (of any type)"177 should be mcluded within the definition. The discussion continued with speculations on the numbers and percentages that might satisfy the term "substantial number":

For example, if there were 500 small organizations of a certain description, and 200 of them would face major new reporting requirements if a certain rule were implemented, then the rule should be expected to have a significant economic impact on a substantial number of small entities (in this case small organizations). If there were ouly 25 small businesses in an industry dominated by 12 large businesses, then a rulemaking initiative which would threaten the economic viability of 15 of those small busmesses, and thus adversely affect competition and industrial concentration, would have a "significant economic effect on a substantial number of sinall entities" within the meaning of the legislation, even though the absolute number of small businesses involved would be minuscule. ${ }^{178}$

Fimally, the report indicated that "economic impacts include effects on competition and econormic concentration," thus suggesting that antitrust market analysis may be relevant. ${ }^{179}$

2. Administrative Implementation of the Certification Process. There are two basic questions that will arise each time an agency decides whether to certify a rule under section 605(b): what is a "significant economic impact," and how many entities constitute a

174. Id. In its discussion, the Senate appeared to equate "overwhelming percentage" with substantial number, although it refused to constrain itself with any particular definition.

175. 126 CoNG. REC. H8468 (daily ed. Sept. 8, 1980).

176. Id. This interpretation is suggested by earlier drafts of the certification section that had uscd the term "substantial adverse" impact and that settled on "substantial impact." See S. 2147, 96th Cong., 1st Sess. \& 634, 125 Cong. REC. S19,039 (daily ed. Dec. 18, 1979).

177. 126 CoNG. REc. H8469 (daily ed. Sept. 8, 1980).

178. Id.

179. $I d$. 
"substantial number"? The questions are interrelated and must be addressed together in the certification process.

In making a section 605 certification, certain steps inust be followed. The certification inust be made by an agency head (or his delegate) and must be published in the Federal Register with a statement of reasons accompanying the notice of proposed rulemaking (if the certification is made at that time). ${ }^{180}$ The agency may decide not to make the certification at this stage because of the uncertain impact on small entities; instead, it will publislı an imitial regulatory-flexibility analysis. ${ }^{181}$ This analysis may be the best way to determine the impact of a particular rule on small entities, because those entities that consider themselves in that category are permitted to address that question during the comment period. Once a certification is made, it inust be forwarded to the SBA's Office of Advocacy. ${ }^{182}$ Although the Chief Counsel of Advocacy is given no particular approval role, he inay object to the certification. According to the House report, his objections should be given "the utmost serious consideration."183

(a) The meaning of "significant economic impact." The purpose of this phrase is to identify a regulation's costs or benefits to small entities. Costs should be isolated and ineasured. For example, an agency should consider an analysis of market sliare before and after the rule. Obviously, a rule that would drive small entities out of a given market would have a significant impact, as would a rule that jeopardizes their competitive position vis-a-vis large businesses. Other costs, so long as they are economic, should be considered. Costs of coinpliance witl the regulation, for example, can be determined on an absolute and on a percentage-of-revenue basis. Reporting requirements may necessitate reorientimg the workload of existimg persolmel or engaging outside professional assistance. ${ }^{184}$ The agency should consider each cost and the net effect of all the costs resulting from the proposed rule.

Assessing the significance of these costs is naturally a subjective process; it is very difficult in the abstract to set objective standards. Compliance costs that equal a small business' profit margin - five to ten percent of annual sales - would satisfy inost business definitions of "significant." If small businesses can reasonably say that the proposed

180. 5 U.S.C. $\$ 605(b)$ (Supp. IV 1980).

181. See id. $\S 603$.

182. $I d . \S 605(\mathrm{~b})$.

183. 126 CoNG. REC. H8469 (daily ed. Sept. 8, 1980).

184. See Office of Management \& Budget, InCorporating Regulatory Flexibllity Into the Regulation Process: InTERIM Guidance 6 (Dec. 1980) [hereinafter cited as OMB INTERIM GUIDANCE]. 
rule would significantly reduce their profit margin, then an agency, acting within the broad mandate of the RFA, should consider the costs "significant." The significance of the impact on small organizations and governmental jurisdictions will also best be determined on the basis of economic cost. Such additional costs must be considered in light of current operational costs in the particular field.

(b). The meaning of "substantial number of small entities." This aspect of the definition is slightly less subjective, because agencies can utilize simple arithmetic to reach a definition of "substantial number." The first step is to calculate the total number of entities affected by the rule; if that number is im the thousands, legislative history (and cominon sense) would designate it substantial. Because the absolute numbers will frequently not be so high, the agency should evaluate other factors, including the ratio of small and large entities affected, the number of industries affected, and the number of geographical areas affected. ${ }^{185}$ The geographical area factor suggests an antitrust relevantmarket definition. ${ }^{186}$ If the proposed rule affects a substantial number of small entities within a given area, the definition can be satisfied even if this number represents a small percentage of the national total. In other words, a rule with only regional impact should not be tested by a national definition of "substantial." Presumably, the converse is also true, and thus small entities should make a careful study of the geographical reach of any rule.

The relevant product inarket is also a useful concept. SBA Standard Industry Codes ${ }^{187}$ provide accepted definitions of particular lines of commerce that may be affected, thereby separating the market into meaningful parts. The question of substantiality will relate to the number of sinall businesses affected within that particular industry. Once the relevant product market is established, one may easily calculate the ratio of affected small entities over all small entities alone or sinall and large entities combined.

The legislative history suggests that forty percent of the small entities in given geographical or product markets would certainly qualify as a "substantial number." 188 "Whether sinaller percentages also qual-

185. See OMB INTERIM GUIDANCE, supra note 184, at 6-7.

186. For a discussion of relevant market shares and anticompetitive effects, see 4 P. AREEDA \& D. TURNER, ANTITRUST LAW $\S 910 a-910$ e (1980).

187. The SBA publishes a Standard Industrial Classification Manual which contains about 950 four-digit designations. See OfFice of Statistical Standards, U.S. DeP'T OF the TreasURY, STANDARD Industrial Classification MaNual (1967).

188. The $40 \%$ figure is derived from the House discussion, see text accompanying notes 177-78 supra, which reasoued that if 200 of 500 small organizations face a particular regulatory burden, it is substantial. The Honse also listed an impact on 15 of 25 small busmesses as substantial. 126 
ify is less clear, but according to the legislative history any formula should be liberally interpreted to effectuate the coverage of the Act. ${ }^{189}$ The substantiality question in the abstract continues to be difficult to answer; thus, the best advice to those seeking coverage is to prepare the strongest statistical case for the highest percentage of small entities affected. ${ }^{190}$

\section{Formulating the Initial and Final Regulatory-Flexibility Analyses.}

An important requirement of the RFA is that agencies proposing rules inust consider the impact of those rules on sinall entities. The "principle of regulatory issuance" postulated by the RFA is that agencies should "fit regulatory and informational requirenents to the scale of the businesses, organizations, and governmental jurisdictions subject to regulation."191 To accoinphish this regulatory "fit," the RFA requires that every proposed rule subject to its jurisdiction be accompanied by an imtial regulatory-flexibility analysis (IRFA) and that every final rule be accompamed by a final regulatory-flexibility analysis (FRFA). 192

Each of these documents has a format with a common-sense purpose: to elicit the consideration, description, and explanation of the use or nonuse of certain regulatory alternatives. ${ }^{193}$ The IRFA should suggest regulatory alternatives such as differmg coinpliance and reporting requireınents (in effect, "tiering"), simplification of those requirements, use of performance rather than design standards, and exemptions froin the rule's coverage. ${ }^{194}$ The FRFA inust contain a succinct stateinent of the need for the rule, a summary of comments on the regulatory-flexibility alternatives, and a description and explanation for rejection of

CONG. REC. H8469 (daily ed. Sept. 8, 1980). Although over-reliance on these percentages is tempting, $40 \%$ or more slould clearly qualify as substantial by any definition.

189. In this context, the House discussion emphasizes that "the legislation is intended to be as inclusive as possible, and doubts about its applicability should be resolved in favor of complying with the provisions of the Act." 126 CoNG. REc. H8468 (daily ed. Sept. 8, 1980).

190. Engaging in this kind of exercise is familiar to antitrust plaintiffs who try to define markets narrowly to maximize a particular firm's impact, and to antitrust defendants, who seek to define markets broadly to minimize their respective firms' impact. See generally 2 P. AREedA \& D. TURNER, supra note $186, \S 507$. In the RFA context, there is not likely to be a party with the imcentives of an antitrust defendant to contradict the proffered small entity definition.

191. Regulatory Flexibility Act of 1980, Pub. L. No. 96-354, § 2(b), 94 Stat. 1164, reprinted in 5 U.S.C. $§ 601$ app., at 124 (Supp. IV 1980).

192. 5 U.S.C. $\$ \S 603-604$ (Supp. IV 1980). The IRFA may be waived or delayed in emergency circumstances if the agency head so states (and provides reasons); the FRFA cannot be waived, but it may be delayed for up to 180 days after the rule is promulgated on proper findings by the agency head. Id. $\$ 608$.

193. Id. $\S \S 603-604$.

194. Id. $\S 603(c)$. 
each "significant" alternative that the agency considered.195 The FRFA must either accompany the final rule or be made available to the public on request. 196 Despite these fairly detailed imstructions, several crucial questions of interpretation and application remain unanswered or madequately resolved. Among these queries are the effect of contradictory substantive law on the regulatory-flexibility process, the actual analytical techniques required to satisfy the regulatory-flexibility process of analysis, and the relationship of the RFA to other regulatoryanalysis requirements.

1. The Effect of Contradictory Substantive Law. The RFA states that it is not intended to contradict the requirements placed on agencies by organic legislation. In fact, the introductory note to the RFA admonishes agencies to engage in regulatory-flexibility analysis if sucl analysis is "consistent with the objectives of the rule and of applicable statutes."197 Section 606 states that "the requireinents of sections 603 and 604 of this title do not alter in any manner standards otherwise applicable by law to agency action." 198 Botli sections 603 and 604 also emphasize that such analysis shall be "consistent with the stated objectives of applicable statutes." 199

The legislative history deals with the question of statutory inconsistency in several ways. It is obvious that Congress did not want to use the RFA as a means of overruling statutory requirements. ${ }^{200}$ The RFA in all likelihood would not liave become law if it ainounted to an implicit rejection of substantive legislative requirements, especially

195. Id. \$ 604. Of course, one of the alternatives discussed in the IRFA may become the one chosen in the final rule, apparently the ideal outcoine under the RFA.

196. No mention is made of who should bear the costs of copying and distribution, which means that the costs will presumably fall on the agency promulgating the rule unless it promulgates rules to the contrary.

197. See Regulatory Flexibility Act of 1980, Pub. L. No. 96-354, § 2(b), 94 Stat. 1164, reprinted in 5 U.S.C. $\S 601$ app., at 124 (Supp. IV 1980). This comment raises some interesting questions. Concerning the requirement that an analysis not be inconsistent with the "objectives of any rule," it may be that the RFA will seek to change the "objectives" of a rule if those objectives unnecessarily burden small entities; indeed, such change is the RFA's purpose. The probable meaning of the term is that the RFA cannot change any rule's objectives if they are mandated by underlying law. On the other hand, most regulatory "objectives" can be reconciled with the RFA by reading the term to apply to those objectives that can be met without inadvertently placing regulatory burdens on small entities.

Section 606 speaks only of sections 603 and 604 not altering applicable agency standards. This formulation presumably frees section 602 (the regulatory-agenda requirement) to suggest alterations in those standards.

198. 5 U.S.C. $\S 606$ (Supp. IV 1980).

199. Id. $\$ \S 603(\mathrm{c}), 604(\mathrm{a})$.

200. Senator Culver's opening statement at the 1979 Regulatory Reform hearings noted "that it is not the purpose of these hearings or of S. 299 to undermine worthwhile Federal regulatory efforts." 1979 Senate RFA Hearings, supra note 133, pt.3, at 2. 
those in the health, safety, consumer, and environmental areas. ${ }^{201}$ Thus, in such areas there was never a case made for giving sinall entities special treatinent.

In some situations, however, it may be difficult to determine whether a particular regulatory alternative will frustrate substantive goals. For example, the use of exenptions from coverage, which is one of the IRFA alternatives listed in subsection 603(c)(4), has the potential to contradict underlying legislation. The legislative history recognizes, however, that there may indeed be situations in which exemptions are impermissible. ${ }^{202}$ That one or more alternatives are impermissible does not necessarily inean that the regulatory-analysis process is unnecessary; rather, as long as some alternative (whether or not it is histed $\mathrm{m}$ Section 603(c)) is feasible or permissible, the agency should follow the IRFA process. Because it is difficult to beheve that every alternative is impermissible, an agency would be liard pressed ever to dispense with the IRFA process.

The one exception to this generalization may occur in those agencies such as OSHA, in which cost-benefit analysis is either forbidden or clearly not required by Congress. The Supreme Court decided in American Textile Manufacturers Institute, Inc. v. Donovan ${ }^{203}$ that Congress does not require a cost-benefit analysis when it speaks of establishing "feasible" standards for dealing with toxic inaterials;"204 therefore, courts may not inandate that agencies perform such analyses. This judicially sanctioned freedoin froin a cost-benefit analysis nay appear to hiberate agencies from the preparation of regulatory-flexibility and other analyses, ${ }^{205}$ but this conclusion can be reaclied only by

201. Senator Culver also stated, "It is not the aim of this legislation to allow the continuation of practices which are dangerous to workers, consumers or the environment." $I d$.

202. The discussion of S. 299 makes the point as follows:

In some rare instances, the adoption of a flexible alternative may clearly be legally impermissible. If so, an agency may so indicate with a simple statement such as: "Under Section $X$ of the $Y$ Act, the agency is required to promulgate these rules in a uniform manner upon all members of the pubhc;" or "Under the Supreme Court decision in X v. $Y$, no exceptions to this rule can be permitted;" or "Differing standards of compliance can be required only under circumstances described in Section A of the B Act, and those circumstances do not occur in this situation."

126 Cong. REC. S10,937 (daily ed. Aug. 6, 1980). See also, 1979 Senate RFA Hearings, supra note 133, pt.3, at 3-11 (testimony of Peter Petkas).

203. 452 U.S. 490 (1981).

204. The American Textile case dealt with a challeuge to OSHA's cotton dust inhalation standard promulgated pursuant to the agency's objectives set out in 29 U.S.C. $\$ 655$ (b)(5) (1976).

205. These other analyses include, im particular, Executive Order 12,291, 46 Fed. Reg. 13,193, reprinted in 5 U.S.C. $\$ 601$ app., at 124 (Supp. IV 1980), which requires executive agencies to determine that the potential benefits to society of a regulatory action outweigh its potential costs before the agency takes action. See notes 231-35 infra and accompanying text. After the American Textile decision, executive agencies such as OSHA might not follow this requireinent. If such 
resorting to an unduly narrow reading of the regulatory-flexibility requirements. The RFA never mentions the term "cost-benefit" in describing the kinds of alternatives it seeks to have agencies consider. Moreover, it does not mandate any particular form of analysis or any given outcome. Therefore, the regulatory-flexibility-analysis process should be applicable even to those agencies such as OSHA that are congressionally freed from the use of cost-benefit analysis. Indeed, smce OSHA itself has recently begun to employ concepts such as tiering in its proinulgation of standards, 206 the implementation of the RFA process should not be difficult. A sensible approach to the regulatory-flexibility-analysis process is for agencies uniformly to prepare an IRFA histing all possible significant alternatives and then to use the comment period to focus on objections to particular alternatives from both legislative and feasibility viewpoints. These objections can be articulated in the FRFA as reasons for rejection of a particular significant alternative.

2. The Analytical Techniques Required or Encouraged by the $R F A$. Agencies must use "regulatory analysis" in preparing the IRFA and FRFA, a term not self-explanatory. A variety of analytical techniques are available, soine more burdensome than others, that would neet the RFA's analysis requirements. Regulatory analysis can be a code word for regulatory paralysis and the drafters were sensitive to the charge that the RFA itself would add another delaying mechanisin to the administrative process. ${ }^{207}$ Congress placed responsibility for com-

agencies choose not to follow the mandate of Executive Order 12,291, the Court's decision protects them; indeed, one can read the decision as forbidding cost-benefit analysis by OSHA, thus preventing OSHA from coinplying with the Executive Order. In any event, the Executive Order's cost-benefit requirements do not extend to independent agencies, unless the RFA were interpreted to require cost-benefit analysis independent of the Executive Order (an interpretation that is not recommended here, but that the OMB may encourage). See notes 228-42 infra and accompanying text.

206. 1979 Senate RFA Hearings, supra note 133, pt.3, at 189 (testimony of Eula Bingham: "For sunall businesses OSHA provides special consideration"). See generally OccuPATIONAL SafeTy and Health Administration, U.S. DEP'T of Labor Occupational Safety and HEALTH ADMINISTRATION's IMPACT ON SMALl BuSINESS (1976).

207. The legislative history divides the problem of administrative efficiency into two considerations. The first objection coucerns the costs to administrative efficiency of imposing yet another analysis requirement upon agencies. The RFA's drafters pointed to the limitations in the RFA to "a significant effect upon a substantial number of small entities," and noted that the goals of the RFA "can be met largely through attentiveness by rulemakers to the unique problems of smaller institutions." See 126 CoNG. REC. S10,938 (daily ed. Aug. 6, 1980). The point of this latter observation is that the Senate did not believe there was a real data collection or analysis problem, but ouly a "lack of interest" by agencies that the RFA seeks to rectify.

The second objection based on administrative efficiency coucerns the disruptive and dilatory potential of judicial review, see notes 268-83 infra and accompanying text. See generally 1979 Senate RFA Hearings, supra note 133, pt.3, at 5 (testimony of Peter Petkas). 
pliance oversight im the Office of Advocacy to emphasize small business interests in government. The Office can be expected to demand much of the regulatory-analysis process, but this arrangement creates inherent tensions that will comphicate the determination of acceptable analytical techniques.

Sections 603 and 604 of the RFA do not identify the analytical techniques an agency should use in discussing suggested regulatory alternatives, but section 607 provides an important guide: "In comply" ing with the provisions of sections 603 and 604 of this title, an agency may provide either a quantifiable or numerical description of the effects of a proposed rule or alternatives to the proposed rule, or more general descriptive statements if quantification is not practicable or rehable."208 This provision and the related legislative history imdicate that the agency is not to perform regulatory analyses that require extensive creation of new data or even elaborate reworking of existing data. Rather it appears that an agency is to rely on existimg data, which may or may not be quantified, and on whatever additional data it receives during the comment process. ${ }^{209}$ If the main problem the RFA seeks to overcome is an agency "lack of interest" in small entities, ${ }^{210}$ then data collection is simply not the thrust of the statute.

This narrow view of the agency's data collection role has important budgetary consequences. The agency will not usually need to commission staff or outside consultants to produce studies on small entity impact, but should be able to incorporate the small entity impact issue into related studies. ${ }^{211}$ This interpretation will surely please agencies, but it may have the opposite effect on the Office of Advocacy, which may envision more stringent regulatory-flexibility responsibilities. $^{212}$ Moreover, the OMB has circulated tentative regulatory-analysis guides that must also be considered.213

If the Office of Advocacy behaves as if compliance witl the requirements of the RFA is the sole responsibility of agencies, it could

208. 5 U.S.C. $\S 607$ (Supp. IV 1980).

209. The Senate section-by-section analysis of the RFA stated that with respect to section 607, "agencies are encouraged to make reasoned estimates or [sic] quantifiable and non-quantifiable effects of various proposals, basing such estimates upon experience and expertise of agency personnel and any other information made available to the agency by external sources." 126 CoNo. REC. S10,942 (daily ed. Aug. 6, 1980).

210. See note 207 supra.

211. See note 209 supra. For a discussion of the question of relating the RFA process to other regulatory analysis requirements, see text accompanying notes 224-54 infra.

212. The Office of Advocacy can be expected to make its view known through the formulation of guidelines for the preparation of RFAs.

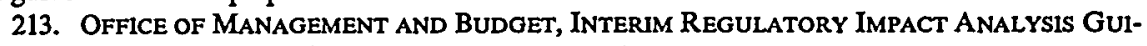
DANCE (1981) [hereinafter cited as OMB GUIDELINES]. 
well establish guidelines that are more onerous than necessary. The temptation is undoubtedly present to postulate standards for creating an "ideal" IRFA and suggestimg that those standards should be the norm. ${ }^{214}$ For example, proposing economic modelling of industries affected by a rule subject to the RFA could result in costly studies by agencies that would consume most of the agency resources available for rulemaking generally. ${ }^{215}$ Such standards would ultimately prove counterproductive ${ }^{216}$ and confirm fears that the RFA will deal a sharp blow to administrative efficiency. An institutional outline or guide to the IRFA that accepts realistic limits on the requirements of agency data collection and organization would best serve the long-run interests of those supporting the RFA.

The OMB has not yet decided whether it intends to propose an official outline. ${ }^{217}$ To date, the OMB approach has simply been to provide an interim outline of the regulatory-impact analysis required under Executive Order 12,291218 and to ask agencies to suggest improvements and ways im which the RFA requirements may be incorporated into the Executive Order. ${ }^{219}$ Thus, the OMB will probably push the RFA process in the direction of the Executive Order regulatoryimpact analysis over which the OMB has jurisdiction. What difficulties, if any, will emerge from this approach are not yet clear. One concern is whether agency compliance will require a thorough cost-benefit analysis, which does not seem to be called for under the RFA. This approach could cause a problem if agencies are not required or even permitted to conduct such analyses. ${ }^{220}$

214. Bureaucratic behavior that seeks to maximize the agency's own particular role is understandable but especially mischievous when one bureaucracy oversees another. In this case, the RFA gives the Office of Advocacy a unique role in emphasizing compliance by rulemaking agencies, a role that can easily be overemphasized.

215. It is possible that the SBA will have already collected some data on industry behavior that would be of use to agencies making industry-specific evaluations through the SBA's codes. However, agencies are also called upon to make impact studies of small organizations and small governmental jurisdictions in situations in whicl there is no data base comparable to that available through the SBA.

216. Burdensoine RFA performance standards would become counterproductive because they would be likely to encourage agencies to opt out of the RFA through the certification process rather than attempt compliance with the IRFA requirements. See text accompanymg notes 170-71 supra.

217. OMB is still circulating a helpful but succinct outline of the IRFA prepared during the closing days of the Carter administration. See OMB INTERIM GUIDANCE, supra note 184.

218. 46 Fed. Reg. 13,193, reprinted in 5 U.S.C app. $\$ 601$, at 124 (Supp. IV 1980).

219. Letter from James C. Miller III, Administrator for Information and Regulatory Affairs, $O M B$, to agency heads (June 12,1981). For a discussion of the interaction between the Executive Order and the RFA, see notes 228-42 infra and accompanying text.

220. See notes 203-05 supra and accompanying text. The ultimate reach of cases like American Textile Mfrs. Inst., Inc. v. Donovan, 452 U.S. 490 (1981), is not yet clear. The Court was not faced 
Some agencies have prepared their own RFA regulatory-flexibility guidelines. The FDA, for example, published a useful guide for its regulation writers and developers when the RFA became effective on January 1, 1981.221 The guide discusses the RFA and related executive orders and outlines various regulatory alternatives (such as tiering, exemptions, and performance standards) that may be useful in preparing regulatory-flexibility analyses. ${ }^{222}$ The FDA guide does not discuss a format for the preparation of an IRFA or FRFA, but it does recommend a procedure for advance notice of proposed rulemaking. This allows early collection of information about a proposed rule, including how the rule will affect small busmess. ${ }^{223}$

At this stage, an agency can experiment with the preparation of IRFAs and still be within the broad outlines of the RFA. It may be that guidelines proposed by the Office of Advocacy or by the OMB will ultimately limit agency experimentation, but there is little evidence that Congress imtended the IRFA to becoine an analytical straightjacket. Section 603 is a clearly expressed provision and it should not pose difficulties for agencies that have personnel with the appropriate analytical skills. Discussion of the significant alternatives will require care and creativity, but there are no unfamiliar concepts to consider. Experience with the process, coupled with a good faith effort to comply, should allow agencies to create satisfactory, if not ideal, regulatory-flexibility analyses.

3. The RFA's Relationship to Executive Order 12,291 and to the Paperwork Reduction Act. Section 605(a) of the RFA emphasizes the avoidance of duplicative or unnecessary analyses: "Any Federal agency may perform the analyses required by sections 602,603 , and 604 of this title in conjunction with or as a part of any other agenda or analysis required by any other law if such other analysis satisfles the

with the question whether OSHA may voluntarily engage in cost-benefit analysis. Therefore, OSHA, as an executive agency, may perform the cost-benefit analyses called for by Executive Order 12,291. But a future litigant will im all likelihood call attention to the Court's language in American Textile that in passing the RFA, Congress lad already balanced the costs and benefits and did not expect the agency to do so again. See id. at 519-22. If this argument succeeds, the Executive Order's requirements could not be imposed and the only regulatory analysis that could operate would be that provided for under the RFA. The Director of OSHA, Thorne G. Auchter, has already indicated that his agcncy will drop plans to apply cost-benefit analysis. N. Y. Times, July 13, 1981, § A, at 11 .

221. See Food and Drug administration, U.S. Dep't of Health and Human Services, Flexible Regulatory alternatives: A GUide for FDA Managers, Regulation Writers AND DEVELOPERS (1981).

222. Id. 3-6.

223. Id. 8. 
provisions of such sections."224 Section 605(c) complements this approach by allowing agencies to combine related rules for purposes of analysis: "In order to avoid duphicative action, an agency may consider a series of closely related rules as one rule for the purposes of sections $602,603,604$ and 610 of this title."225 The obvious intent of these provisions is to encourage administrative efficiency in the preparation of regulatory analyses. There are numerous opportunities for integrating regulatory-flexibility requirements into existing regulatory analyses. Many agencies, as a matter of common sense, focus on regulatory alternatives during rulemaking; achieving the proper fit between the regulation and the regulated (the RFA principle) is not a new idea. In other situations, Congress specifically encourages agencies to undertake analyses when small businesses are involved, and with only slight modifications this same analysis could satisfy the IRFA requirements. 226 Furthermore, the collection and organization of existing data may be adequate to satisfy the RFA requirements. In addition to congressionally mandated analyses, the requirements imposed by Executive Order 12,291 and the Paperwork Reduction Act ${ }^{227}$ can also be integrated into the RFA process.

(a) The RFA and Executive Order 12,291. Executive Order 12,291, issued by President Reagan on February 17, 1981,228 is designed to minimize duplication and conflict of regnlations and to ensure well-reasoned regulations. Much like the RFA, the Executive Order requires a regulatory-impact analysis that hists regulatory alternatives, but it departs from the RFA in that it apphes only to "major rules" 229 issued by executive agencies. ${ }^{230}$ Unlike the RFA, it emphasizes cost-benefit analysis. ${ }^{231}$ The Executive Order is nore einphatic than the RFA, instructing agencies not to promulgate rules unless the potential benefits to society outweigh the potential costs. On

224. 5 U.S.C. § 605(a) (Supp. IV 1980).

225. Id. $\S 605(\mathrm{c})$.

226. In FTC rulemaking, for example, the Commission is required to publish an advance notice of rulemaking that discusses "possible regulatory alternatives." 15 U.S.C. $\& 57 \mathrm{a}(\mathrm{b})(2)(A)$ (Supp. IV 1980). When the Commission promulgates a rule, the statement of basis and purpose must contain "a statement as to the economic effect of the rule, taking into account the effect on small busmess and consumers." Id. §57(a)(d)(1).

227. 44 U.S.C.A $\$ \S 3501-3520$ (West Supp. 1981).

228. 46 Fed. Reg. 13,193 (1981), reprinted in 5 U.S.C. app. § 601, at 124 (Supp. IV 1980).

229. Major rules are defined as those likely to result in "[a]n annual effect on the economy of $\$ 100$ million or more." $I d .1$ (b)(1). In addition, the Director of the OMB is granted the authority to prescribe further criteria for defining a major rule, $i d . \S 3(\mathrm{~b})$, and may actually designate a rule as major. Id. $\S \S 3(\mathrm{~b}), 6(\mathrm{a})(1)$.

230. See id. $\S 1$ (d).

231. Id. $\S 2$. 
the other hand, the RFA permits any regulatory outcome so long as the alternatives are rejected after reasoned consideration.

Frequently, regulatory-impact analysis and regulatory-flexibility analysis will both be applicable to a proposed rule. ${ }^{232}$ The RFA and the Executive Order contemplate such overlaps and urge that the analyses be coinbined. ${ }^{233}$ In each case a two-stage analysis, mcluding a preliminary and final step, is contemplated.234 The cost-benefit approach of the Executive Order nay also constitute a "significant alternative" for purposes of IRFA analysis unless that approach is forbidden by organic legislation. ${ }^{235}$

Complications arise when an agency must submit its preliminary or mitial analyses for review. Under the RFA, all IRFAs must be transmitted to the Office of Advocacy, but that Office has no direct role in the ruleinaking process. ${ }^{236}$ Under the Executive Order, the preliminary and final regulatory impact analyses nust be submitted to the Director of the OMB for review..$^{237}$ The agency nust then consult with

232. The definition of "rule" is broader under Executive Order 12,291 than it is under the RFA. The Executive Order does not tie the definition directly to the APA and it covers interpretative rules that the RFA definition excludes. Compare id. \& 1(a) with 5 U.S.C. \& 601(2) (Supp. IV. 1980). See notes 154-61 supra and accompanying text. Also, the Executive Order directs that a final regulatory-impact analysis be prepared for those rules that are not energency rules and for which no notice of rulemaking has been published. Exec. Order No. 12,291, \&3(c)(1), 46 Fed. Reg. 13,193 (1981), reprinted in 5 U.S.C. § 601 app., at 124 (Supp. IV 1980).

233. See. 5 U.S.C. \& 605 (Supp. IV 1980); Exec. Order No. 12,291, § 3(a), 46 Fed. Reg. 13,193 (1981), reprinted in 5 U.S.C. \$ 601 app., at 124 (Supp. IV 1980).

234. These are called a preliminary and final regulatory impact analysis under the Order and an IRFA and FRFA under the RFA.

235. See notes 197-202 supra and accompanying text. The Executive Order specifies that each preliminary and final analysis contain the following information:

(1) A description of the potential benefits of the rule, including any beneficial effects that cannot be quantified in monetary terms, and the identification of those likely to receive the benefits;

(2) A description of the potential costs of the rule, including any adverse effects that cannot be quantified in inonetary terms, and the identification of those likely to bear the costs;

(3) A determination of the potential net benefits of the rule, including an evaluation of effects that cannot be quantified in inonetary terms;

(4) A description of alternative approaches that could substantially achieve the same regulatory goal at lower cost, together with an analysis of this potential benefit and costs and a brief explanation of the legal reasons why such alternatives, if proposed, could not be adopted; and

(5) Unless covered by the description required under paragraph (4) of this subsection, an explanation of any legal reasons why the rule cannot be based on the requirements set forth in Section 2 of this Order.

Exec. Order No. 12,291, § 3(d)(1)-(5), 46 Fed. Reg. 13,194 (1981), reprinted in 5 U.S.C. § 601 app., at 124-25 (Supp. IV 1980).

236. See 5 U.S.C. $\S 603$ (Supp. IV 1980). The FRFA need not be submitted to the Office of Advocacy. See id. $\$ 604$.

237. To allow the Director to conduct this review, an agency unust submit the preliminary analysis sixty days before publication of the notice of proposed rulemaking and the final analysis thirty days before promulgation of the final rule. Exec. Order No. 12,291 §3(c), 46 Fed. Reg. 
the Director and refrain from publishing its notice or promulgating its final rule, as the case may be, during the consultation process. ${ }^{238}$ The Executive Order stops short of forbidding publication or promulgation if the consultation process is unsuccessful, but it obviously contemplates a much more direct coordimation role for the OMB than does the RFA for the Office of Advocacy. Assuming a rule is subject to both analyses, there is no apparent way to avoid the OMB consultation process for RFA rules unless legislation declares to the contrary, either directly or by establishing time limits on rule promulgation. ${ }^{239}$

The Executive Order process clearly dominates when rules are subject both to regulatory analysis under the Executive Order and to regulatory-flexibility requirements under the RFA. The RFA process will operate freely only in those rulemaking circumstances in which the Executive Order does not apply. These circumstances include all independent agency rulemaking and any executive agency rulemaking that involves rules having an impact of less than $\$ 100$ million on the economy, ${ }^{240}$ a category imto which a large number of rules will fall. ${ }^{241}$ The Office of Advocacy is well advised to consolidate its oversight resources over these rules and leave the other rules to the OMB to review under the Executive Order, unless there are strong pro-small-busmess reasons for joining in the OMB's review process. ${ }^{242}$

(b) The RFA and the Paperwork Reduction Act. The Paperwork Reduction Act of 1980,243 designed with small business specifically in mind, establishes standards for the review and reduction of reporting and paperwork requirements. ${ }^{244}$ It gives the OMB, through the newly created Office of Information and Regulatory Affairs (OIRA), responsi-

13,194-95 (1981), reprinted in 5 U.S.C. $\$ 601$ app., at 124-25 (Supp. IV 1980). Even if it is not "major," each rule must be submitted to the Director at least ten days before publication and promilgation, respectively. Id. $\S 3(\mathrm{c})(3)$.

238. Exec. Order No. 12,291, §3(f)(1) - (2), 46 Fed. Reg. 13,195 (1981), reprinted in 5 U.S.C. app. § 601 app., at 125 (Supp. IV 1980).

239. The Executive Order states that it does not apply when its deadlines conflict with deadlines imposed by statute or judicial order. $I d . \S 8(2)$.

240. See id. \&1(b)(1).

241. Independent agencies such as the SEC, the FTC, the ICC and the Consumer Product Safety Commission issue many regulations that concern small busmess. The $\$ 100$ million threshold for Executive Order regulations excludes from coverage executive agency regulations that probably number in the thousands.

242. One can foresee the OMB's willingness to allow the Office of Advocacy to take the lead concerning regulatious that exceed $\$ 100$ million if the regulations have a significant impact on small business and if the OMB and the Office of Advocacy lrave a good working relationship.

243. 44 U.S.C.A. $\$ \$ 3501-3520$ (West Supp. 1980).

244. The first purpose of the Act is "to minimize the Federal Paperwork burden for individuals, small businesses, State and local governments, and other persons." Id. § 350I(1) (empliasis added). See also White House COMM'N, supra note 24, at 29 (calling for the elimination of onerous reporting requirements). 
bility for review of the information policies of independent and executive agencies and mandates a reduction in federal paperwork by October, 1983.245

The Act imposes several duties on agencies and on the OMB with regard to rulemaking. At the time the notice of a proposed rulennaking is published, agencies must forward to the OIRA copies of all proposed rules that require collection of information. ${ }^{246}$ Within sixty days after receipt of these rules, the OIRA may file public comments on the rules' information-collection requirements and the agency inust respond to these comments in its final rule. Within sixty days of the publication of the final rule, the OMB (through the OIRA) may disapprove any collection of information it deems unreasonable. ${ }^{247}$

The OMB's control over agency rulemaking under the Paperwork Reduction Act could affect rulemaking proceedings that are also subject to the RFA. The Office of Advocacy may have to coordimate its regulatory-flexibility function with the OMB when the Paperwork Reduction Act applies. ${ }^{248}$ Undoubtedly there will be circumstances in which the Office of Advocacy will respond to information-collection regulations by recommending alternatives which exempt small entities or reduce the collection burden such entities would otherwise bear. In these circumstances, the Office of Advocacy has an ally in the OMB and the Paperwork Reduction Act. However, there will be an inevitable shift of agency attention away from the RFA under these circumstances because the $\mathrm{OMB}$ generally has a stronger influence on agency behavior. ${ }^{249}$

One important purpose of the Paperwork Reduction Act is to serve through the Federal Information Locater Systein as a collector of information about reporting requirements. ${ }^{250}$ This system, to be mamtamed by the OIRA, is to collect and to index agency requests for data collection and is thus to facilitate the cooperative exchange of data ainong agencies and the reduction of requests for new data. ${ }^{251}$ This capability

245. See 44 U.S.C.A. $\S \S 3504,3505$ (West Supp. 1981).

246. Id. \& 3504(h)(1)-(5).

247. Id. $\S 3507(\mathrm{~b})$. An independent agency may overrule OMB disapproval of its information-collection request by a majority vote of its members. Id. at $\$ 3507$ (c).

248. Because the Paperwork Reduction Act reaches imdependent agencies it may have a greater overlap with the RFA than does Executive Order 12,291.

249. Under the Paperwork Reduction Act, OMB reports to Congress about agencies which violate the Act. 44 U.S.C.A. § 3514(a)(7) (West Supp. 1980). This reporting function is similar to the Office of Advocacy's annual report to the President and Congress under the RFA. See 5 U.S.C. § 612(a) (Supp. IV 1980).

250. See 44 U.S.C.A $\$ 3511$ (West Supp. 1980).

251. Before seeking information, agencies must check with OMB to determine if the data, or substantially similar data, already exists in the systenn. See id. $\S \S 3508-3510$. 
should be of use to the Office of Advocacy in its inonitoring of agency rulemaking because one of the purposes of IRFA is to identify duplicative federal rules and reporting requirements. ${ }^{252}$ In effect, the OIRA will collect useful information that will assist both the Office of Advocacy and the agencies themselves in complying with the RFA requirements.

The interaction of the RFA, the Paperwork Reduction Act, and Executive Order 12,291 may sound harmonious in theory, but there is real potential for delay and confusion in practice. Agencies inay find themselves with three new directives to consider before publishing proposed rules for comment, ${ }^{253}$ a situation that would considerably delay the rulemaking process (perhaps this is one of the unarticulated purposes of regulatory analysis) $)^{254}$ and that would require agencies to develop special expertise in juggling the various new delnands on the rulemaking process.

\section{E. Reviewing Existing Rules and Establishing Agendas.}

The RFA imposes two further responsibilities on agencies that promulgate rules. Under section 602 an agency inust establislı regulatory-flexibility agendas, to be published semiaumually in the Federal Register, ${ }^{255}$ and under section 610 it must publish and implenient a plan for reviewing the impact of existing rules on sinall entities. The rules covered are those likely to have a significant economic impact on a substantial number of small entities. Each rule must be summarized and given a timetable according to which action on the rule will be completed. ${ }^{256}$ The agenda goes to the Office of Advocacy for comment and is available for review by small entities or their representatives. The purpose of the agenda is to provide small entities with another kind of early warning system. ${ }^{257}$ It does not, however, bind an agency

252. See 5 U.S.C. \& 603(b)(4)-(5) (Supp. IV 1980).

253. The Appendix contains a chart showing how the requirements of the RFA, the Executive Order, and the Paperwork Reduction Act interact.

254. On the advisability of "slowing the regulatory process to a crawl" as a means of deregulation, see Eads, supra note 60, at 26.

255. 5 U.S.C. $\$ 602$ (a) (Supp. IV 1980). The RFA does not specify any particular dates within these months because of the need to coordinate publication submission dates with the Office of the Federal Register. See OMB INTERIM GUIDANCE, supra note 184. For a good example of a regulatory agenda incorporating section 602 requirements with those of other regulatory agendas, see 46 Fed. Reg. 53,990 (1981) (EPA Regulatory Agenda).

256. 5 U.S.C. \& 602(a) (Supp. IV 1980). This timetable applies only to those rules that have been subject to a notice of proposed rulemaking. The Senate analysis makes clear that the agenda does not force agencies to announce rulemaking proceedings that are still in the planning stage. 126 Cong. ReC. S10,941 (daily ed. Aug. 6, 1980).

257. See 126 Cong. Rec. S10,941 (daily ed. Aug. 6, 1980). 
to inake future determinations in accordance with its terms..$^{258}$

Executive Order 12,291 also requires the publication of a regulatory agenda, which nay be incorporated into the RFA section 602 agenda. ${ }^{259}$ The substantive requireinents of the Executive Order agenda are phrased in language similar to that of the RFA, except that the former is directed at inajor rules rather than at rules having a significant economic impact.260 The intent of the Executive Order is to avoid duplication by coordinating its requirements as neatly as possible with those of the RFA. The Executive Order does, however, add the requirement that existing regulations be reviewed in its agenda, a subject the RFA treats separately. ${ }^{261}$

The RFA's plan for reviewing existing rules is a basic part of its goal of reducing the burden of regulation on small entities. The plan works on the sensible assumption that much burdensome regulation is already in effect and it seeks to have agencies systematically review such regulations under an established schedule. The agency must pubhish the review plan within 180 days after the effective date of the RFA - July 1,1981 - and the plan must provide for a review every ten years. ${ }^{262}$ Review of existing rules imposes an enormous administrative burden on the responsible agency, for the agency must first review all of its rules to determine whether the rules have a significant economic impact on a substantial number of small entities, a complex determination in itself. Then the agency must assess the following:

(1) the continued need for the rule;

(2) the nature of complaints or comments received concerning the rule froin the public;

(3) the complexity of the rule;

(4) the extent to which the rule overlaps, duplicates or conflicts with other Federal rules, and, to the extent feasible, with State and local governmental rules; and

(5) the length of time since the rule has been evaluated or the degree to which technology, economic conditions, or other factors have changed in the area affected by the rule. ${ }^{263}$

These factors, similar to those listed in an earlier Executive Order

258. See 5 U.S.C. $\$ 602$ (d) (Supp. IV 1980).

259. Exec. Order No. 12,291, § S(a), 46 Fed. Reg. 13,193, 13,195 (1981), reprinted in 5 U.S.C. $\S 601$ app., at 125 (Supp. IV 1980).

260. See notes 229-30 supra and accompanying text. The similar phraseology suggests the drafters of the Executive Order borrowed their language from the RFA.

261. Exec. Order No. 12,291, § 5(a)(3), 46 Fed. Reg. 13,193, 13,195 (1981), reprinted in 5 U.S.C. $\S 601$ app., at 125 (Supp. IV 1980).

262. This period can be expanded annually, on notice, for an additional five years. 5 U.S.C. $\S 610$ (a) (Supp. IV 1980).

263. Id. $\S 610(b)(1)-(5)$. 
issued by President Carter, ${ }^{264}$ are described in the legislative history of the RFA as non-burdensome because of their familiarity. ${ }^{265}$ Obviously, however, this review process will require a great deal of agency effort, which implies that the real purpose of this burden is to keep an agency from doing anything but reviewing rules. ${ }^{266}$

Despite its list of factors, the RFA does not aid agencies in setting priorities for reviewing rules. Given the burden on an agency to conduct the review in the first place, it is important to establish some method whereby the rules most burdensome on small entities are considered first. One approacli is to use the factors themselves to estabhish priorities. 267 For example, the complaimts received about a rule may mdicate what burdens that rule imposes. An agency can refine complaint data, analyzing the complaimt by type and characteristics, and develop a coefficient of regulatory burden for each of its existing rules. An agency that sets review priorities based on an analysis of complaints may be operatimg more efficiently than other agencies even if it reviews fewer existing regulations.

\section{F. The Role of Judicial Review.}

The RFA contaims an extremely qualified and ambiguous provision for judicial review; yet, much of the RFA's enforcement potential depends on the interpretation of this provision. Section 611 provides:

(a) Except as otherwise provided in subsection (b), any determination by an agency concerning the applicability of any of the provisions of this chapter to any action of the agency shall not be subject to judicial review.

(b) Any regulatory flexibility analysis prepared under sections 603 and 604 of this title and the compliance or noncompliance of the agency witl the provisions of this cliapter sliall not be subject to judicial review. When an action for judicial review of a rule is instituted, any regulatory flexibility analysis for such rule shall constitute part of the whole record of agency action in connection with the review.

(c) Nothing in this section bars judicial review of any other impact statement or similar analysis required by any other law if judi-

264. Exec. Order No. 12,044, 3 C.F.R. 671 (1978), revoked by Exec. Order No. 12,291, 46 Fed. Reg. 13,193, reprinted in 5 U.S.C. $\$ 601$ app., at 124 (Supp. IV 1980).

265. See 126 Cong. Rec. S10,942 (daily ed. Aug. 6, 1980).

266. Consider the requirement that a rule be reviewed to determine conflict or overlap with federal, state, and local rules. There are few existing guides to detect current conflicts between federal regulations (imdeed the Code of Federal Regulation still lacks a comprehensive index) and no guides helpful for comparing state and local rules, which are not even published in inany cases.

267. Executive Order 12,044 also adds some useful criteria for setting review priorities, such as burdens imposed by the rule and the need for clarifying language. See 3 C.F.R. 674 (1978), revoked by Exec. Order 12,291, 46 Fed Reg. 13,193 (1981), reprinted in 5 U.S.C. § 601 app., at 124 (Supp. IV 1980). 
cial review of such statement or analysis is otherwise provided by law. 268

On its face, this provision seems more like a statement of non-reviewability than of reviewability, but by mcluding the IRFA and the FRFA as part of the whole record it obviously contemplates some manner of judicial review of the RFA process. The purpose of this provision can be best understood by an examination of the relevant legislative history.

1. Legislative Background. Section 611(a) is a clear non-reviewability provision for actions under the RFA other than the regulatoryflexibility analyses of sections 603 and 604. Thus, the following are beyond judicial scrutiny: an agency decision under section $605(\mathrm{~b})$ to certify a rule as not having a significant economic impact on a substantial number of small entities; agency actions under sections 602 and 610 concerning the regulatory agenda or periodic review of existimg rules; or any procedural decisions under sections 608 and 609.269 This is the clear import of section 611(a) and the relevant legislative reports. ${ }^{270}$ In effect, Congress subordinated the value of compliance induced by judicial oversight to the values of administrative efficiency and uninterrupted decisionunaking. ${ }^{271}$ Even though the non-reviewability of the certification process may frustrate the RFA's purpose, Congress chose to take this risk rather than embroil the process in the quagmire of litigation. 272

268. 5 U.S.C. \& 611 (Supp. IV 1980).

269. In emergency circumstances, $\S 608$ provides for waiver of an IRFA and for delay of a FRFA for up to 180 days. The rule concerns lapses if the FRFA is not completed by then, but \$611(a) apparently bars judicial enforcement of this "lapse." Section 609 establislres procedures for gathering comments from small entities.

270. The Seuate sectiou-by-section analysis of S. 299 states:

Section 611(a) provides that there is no judicial review of any deternination by an agency regarding the applicability of any provision of this subcliapter except as provided in Section 611(b). This means, for example, that the decision by an agency with respect to what proposed rules would have a significant econounic impact on a substantial number of small entities pursuant to Section 605(b) shall not be subject to judicial review. Thus, the decision regarding when the ageucy shall conduct a regulatory flexibility analysis remains in the sole discretion of the agency. Also not subject to judicial review are agency determinations regarding the agenda (section 602), the procedures for gathering comments (section 609), the periodic review of rules (section 610) and any other administrative determinations under this act.

126 Cong. Rec. S10,942-43 (daily ed. Aug. 6, 1980).

271. In the Senate discussiou, the judicial review (or non-review) provision is addressed as a solution to the perceived problem of "mcreased litigation" and "uudue delay." See id. S10,937.

272. In one respect the certification process does hint at some judicial oversight. If an agency improperly nses the certification process (as determined by the Office of Advocacy) and later promulgates a rule, one can argue that the rule will lapse in 180 days for failure to supply a FRFA, per $\S 608(b)$. There is a question, however, who can raise this "lapse" and in what forum. Judicial review seems imappropriate becanse of $\$ 611$ (a). Appareutly, Congress did not envision judicial review as the mcthod to pohice improper certifications or improper emergeucy determina- 
Section 611(c) simply declares the obvious: nothing stated about judicial review in the RFA is intended to affect review of any impact statement mandated by other law. ${ }^{273}$ This provision is not discussed in any detail in the legislative reports, but Congress apparently perceived the possibility that combining regulatory-flexibility analyses with other analyses (such as the regulatory-impact analysis required by Executive Order 12,291) might unintentionally lead to a change in the standards of judicial review. ${ }^{274}$ Because the subsection is only a cautionary one, however, it has no real bearing on the question of the role of the courts under the RFA. The subsection that raises that question is 611(b).

Section 611 emerged late in the legislative process. Senate bill S. 299 contaimed no specific judicial-review provision when it was introduced into the Senate in the Ninety-sixth Congress and reported out of the Judiciary Committee on May 5, 1980.275 That version had grafted the substantive provisions of the RFA into the APA, primarily section 553 of the APA. As a result of failing to inention judicial review at this point, the Senate recognized that the judicial-review provisions of the APA would apply to review under the RFA amendments: "The bill does nothing to alter the right of review of agency action as outlined in 5 U.S.C. § 702."276 When the bill went to the Senate floor for passage, however, the RFA was recodified as a separate section of the APA, acquiring section 611 .

The Senate beheved it was achieving a balance between the nonreviewability provisions of related legislation ${ }^{277}$ and the full reviewability of the APA by adding section 611:

tions. See note 269 supra. In effect, the policing mechanism is the Office of Advocacy's annual reports to the President and to Congress.

273. See 5 U.S.C. \& 611(c) (Supp. IV 1980).

274. President Carter's Executive Order 12,044, 3 C.F.R. 671 (1978), revoked by Exec. Order No. 12,291, 46 Fed. Reg. 13,193 (1981), reprinted in 5 U.S.C. $§ 601$ app., at 124 (Supp. IV 1980), contained an explicit provision barring judicial review of its regulatory analyses. President Reagan's Executive Order 12,291, 46 Fed. Reg. 13,193 (1981), reprinted in 5 U.S.C. \$ 601 app., at 124 (Supp. IV 1980), contains a judicial review provision that is equally as anbiguous as that in $\S 611(b)$ of the RFA:

This Order is intended only to improve the internal management of the Federal government, and is not intended to create any right or benefit, substantive or procedural, enforceable at law by a party against the United States, its agencies, its officers or any person. The determinations made by agencies under Section 4 of this Order, and any Regulatory Impact Analyses for any rule, shall be inade part of the whole record of agency action in counection with the rule.

Id. $\S 9$. Because this provision is similar to $\S 611$, any judicial interpretations it receives will bear upon $\S 611$.

275. See S. 299, supra note 83.

276. S. REP. No. 878, 96th Cong., 2 d Sess. 9 (1980) accompanying S. 299.

277. See S. 262, 96th Cong., 1st Sess. § 607, 125 Cong. REC. S861 (daily ed. Jan. 31, 1979); S. $755, \S 603$ 96th Cong., lst Sess. § 603, 125 CoNG. REC. S3338 (daily ed. Mar. 26, 1979) (the Senate and Carter Administration omnibus regulatory-reform bills). 
[T]he bill strikes a balance between two central aims with regard to the role of the courts. The first is to insure that an agency's coinpliance with the objectives of this bill be subject to meaningful, yet responsibly defined, judicial oversight. A flat prohibition of any such oversight might give the erroneous impression that regulatory flexibility provisions may be ignored with impunity . . . .

On the otler hand, the bill avoids the substantial disruption of agency rulemaking inherent in allowing separate judicial review of the regulatory flexibility analysis itself . . . .278

This balance was partially the result of the Senate's belief that to try to prevent a reviewing court from examining the regulatory-flexibility analysis would be "unrealistic."279 The most satisfactory compromise, therefore, was to permit a court to consider the final regulatory-flexibility analysis as part of the whole rulemaking record, yet not to allow the FRFA to be the separate subject of judicial review. This compromise is ambiguous, however. Forbidding "separate judicial review" can be read to mean forbidding not only interlocutory review but also "separate" review of the FRFA as part of the evaluation of the underlying rule.

2. Problems of Interpretation. Apparently the FRFA exists for the court to read, but not to evaluate, a difficult distinction for any reviewing tribunal to draw. If the FRFA is so poor as to be worthless, or is prepared manifestly in bad faith, is a reviewing court to ignore challenges to the FRFA's validity when they are pressed by the Chief Counsel for Advocacy? In those circuunstances many judges would be tempted to conclude that they are empowered to hold the FRFA as well as the resulting rule arbitrary and capricious. But if the court is not reviewing the FRFA in the first place, then any weakness in the FRFA should be irrelevant to the decision whether to uphold or overturn the rule to which the FRFA relates. ${ }^{280}$ Under this view, the FRFA will be

278. 126 Cong. Rec. S10,939 (daily ed. Aug. 6, 1980).

279. Id. The Senate may have been mindful of the earher testimony of the late Judge Harold Leventhal (in connection with S. 262 and S. 755) on the court's role in considering "non-reviewable" analyses, as of the Clean Air Act Amendments, 42 U.S.C. $\$ 7617$ (Supp. 111 1979), to which Judge Leventhal referred. Judge Leventhal took the position that the reviewing court should consider any documents or analyses in the record that help it determine whether the rule itself is a valid exercise of administrative power. See 1979 Senate RFA Hearings, supra note 133, pt. 1, at 623.

280. In an exchange with Judge Leventhal during the hearings on the RFA, Senator Culver asked the following question: "If an agency, for example, stated that it relied on an impact analysis and the analysis was, in the judgment of the court, viewed to be arbitrary or capricious, could the rule itself then not be considered to be arbitrary and capricious?" The Judge replied as follows: "I think that the function of the regulatory analysis in that case would only be to indicate what the agency meant in its rule and what the agency was doing in its rule." 1979 Senate RFA Hearings, supra note 133, pt. 1, at 14. 
of assistance to the court in determining the meaning of the rule, but it should not itself lead to an overturning of the rule..$^{281}$

The legislative history does not fully endorse this narrow view of the role of judicial review. Both the Senate and the House discussions indicate that failure to complete a FRFA, or preparing it inadequately or in bad faith "would be grounds for finding the rule unreasonable under established case law."282 This interpretation conflicts with the idea that the regulatory analysis is to be used only as a suppleinent to the record, not as the subject of independent judicial review. Furtherinore, the court is in a conceptual bind in determining whetler the agency performed the FRFA inadequately or im bad faitli. The standards for judging regulatory analyses are liardly well establislied and the regulatory-analysis process itself is experimental.

Thus, the legislative history raises the twin possibilities that section 611(b) inay serve either as an independent ground for reviewing the adequacy of the FRFA or only as an additional basis for review of the underlying rule. It inay not be necessary in the usual case, however, to determine which possibility is correct, for in inany situations poor performance in the preparation of a FRFA will carry over to inadequate preparation of the rule itself. Moreover, poor performance on the

281. This seems to be the view Judge Leventhal expressed. See notes 279-80 supra. On the other hand, a sloppy or manifestly imadequate FRFA may imdicate to the court that the rule itself has not been adequately prepared. Judge McGowan has suggested that the presence of a regulatory analysis in the record may affect the court's judgment about the rule's validity, either positively or negatively, depending on the quality of the analysis. See Address by C. McGowan, American Ass'n of Law Schools Conference (Jan. 4, 1981).

282. The Senate section-by-section analysis containing that conclusion reads as follows:

For example, in the unlikely event that following an agency head's decision not to certify that a particular rule will have no significant economic impact on a substantial number of small entities (pursuant to Section 605(b)), the agency then completely ignores the resulting requirement to perform regulatory flexibility analyses, an injured party would have grounds to argue that this fact is evidence of the unreasonableness of the rule. Similarly if it can be demonstrated that a regulatory flexibility analysis has not been prepared in good faith and the agency therefore is unable to provide substantive grounds supporting the final rule in the stateinent of basis and purpose, the court would have grounds to invalidate the rule. In addition, if an agency completely fails to respond to a clearly available significant alteruative to the rule less burdensoine on sinall entities and raised in public comments, then this failure would be grounds for finding the rule unreasonable under established case law. See Portland Cement v. Ruckelshaus, 486 F.2d 375 (D.C. Cir. 1973), cert. denied. 417 U. S. 921 (1978); and Automotive Parts and Accessories v. Boyd, 407 F.2d 330, 338 (D.C. Cir. 1968); see also Kennecott Copper Corp. v. EPA, 462 F.2d 846, $849-50$ (D.C. Cir. 1972).

126 Cong. REC. S10,939 (daily ed. Aug. 6, 1980).

In the House the following exchange on judicial review under S. 299 took place:

MR. BROOMFIELD. But what if the agency fails to do this analysis, or if the analysis is inadequate, sloppy or incoinplete?

MR. McDADE. Let me say unequivocally as a member of the committee that wrote this bill, that in that instance, upon review of the final regulation, it is the intent of our committee that the court should strike down the regulation.

126 Cong. Rec. H8463 (daily ed. Sept. 8, 1980). Mr. McDade was a meinber of the committee that drafted H.R. 4660, not S. 299. 
FRFA will undoubtedly color the court's view of the rule in question. Should poor (or pro-forma) FRFA performance, however, not be reflected in the preparation of the underlying rule, ${ }^{283}$ the courts should then rely on the underlying policies of the RFA to determine the appropriate scope of judicial review. Ardent supporters of the RFA will prefer broader, more liberal judicial review, which by its nature will improve chances of agency compliance with the RFA's analysis requirements. The RFA, lowever, is not designed to trigger judicial intervention in the usual sense, for it does not adopt the APA judicial review provisions. The most that can be said is that in designing the judicial review provisions of the RFA, some members of Congress beheved that in egregious cases of noncompliance the courts should intervene on review of the underlying rule. That belief nnay convince a reviewing court occasionally to assert itself in the RFA compliance process.

\section{G. The Role of the Office of Advocacy.}

The ultimate success of the RFA rests on the shoulders of the Chief Counsel for Advocacy. Section 612 requires the Chief Counsel to moritor agency compliance with the RFA and to submit coinpliance reports at least annually to the President and to Congress. ${ }^{284}$ This section also grants the Chief Counsel the right to intervene in any rulemaking review proceeding to present his views on the effect of the proposed rule on small entities, and requires agencies to report nnany of their activities to the Chief Counsel. Because the RFA does not rely on judicial enforcement by private parties, the Chief Counsel is in effect the sole policeman. It is a complex role with unany pitfalls, most of whicl can be avoided by a person with keen political instincts.

1. The Chief Counsel's Monitoring Role. Under the RFA the Chief Counsel receives the regulatory-flexibility agendas, ${ }^{285}$ initial regulatory-flexibility analyses, ${ }^{286}$ and certifications declaring the inapplicability of the RFA.287 Because these reports will inundate the Office of Advocacy, the Chief Counsel must effectively monitor thein to m1-

283. See note 282 supra. It is not difficult to conceive of a situation in which the FRFA was poorly done because the agency believed the small business concerns to be of marginal relevance to the underlying rule and not worth the effort at compliance which the Office of Advocacy might expect. At the same time the rule itself could be the product of careful analyscs. Of course in this situation, the agency might be better advised to certify out of the RFA under $\$ 605(\mathrm{~b})$ rather than run the risk of jcopardizing the support of the rule on appeal through a poorly prepared FRFA.

284. 5 U.S.C. $\$ 612$ (Supp. IV 1980).

285. See id. $\$ 602$.

286. See id. $\$ 603(a)$.

287. See id. $\$ 603(\mathrm{~b})$. 
plement the goals of the RFA. Furthermore, because neither the agendas, the IRFA's, nor the certifications are subject to judicial review, the Chief Counsel creates the only incentives for comphiance.

Because many governmental agencies are unfamiliar with the Office of Advocacy, its first step is to gain the attention of the affected agencies and then to turn that awareness into a credible force for comphance. Only an effective Chief Counsel and a dedicated staff, using all available persuasive tools, can produce the incentives for comphance. For example, periodic reports to the President and to Congress regarding the cooperation of individual agencies can form "winners and sinners" hists that may be influential in determining reappointments and budgets. Also, the Chief Counsel's willingness to intervene in rulemaking appeals from recalcitrant agencies should give the courts an awareness of particular problem areas.

2. The Personnel Needs of the Office of Advocacy. The inost difficult problem for the Chief Counsel will be to assemble a staff large enough to undertake the monitoring process. When it passed the RFA, Congress estimated approximately five hundred rules a year would require regulatory-flexibility analysis. ${ }^{288}$ That estimate appears to understate the actual workload, for even with the restraimts on rulemaking imposed by the Reagan administration, ${ }^{289}$ in the first seven months of the RFA's existence 290 the Office of Advocacy has noted about one thousand rules, for which the Office received about twenty IRFA's and approximately eight hundred certifications. In the period of July 1 , 1981 to October 1, 1981, 412 out of the 489 RFA dispositions were certifications. ${ }^{291}$ This apparent imbalance between certifications and IRFA's is a matter of concern, because as a practical matter the Office of Advocacy must concentrate on certifications as much as it does on IRFA's.

At present the Office has about twenty-five attorneys assigned to $i^{292}$ as well as approximately eight tramed economists. The RFA does not mcrease this level of professional staffing, and given the current general cutback in federal manpower, it is unlikely that additional support will be forthcoming. As presently organized, the Office has nonprofessional imtake personnel assigned to each agency or group of

288. 126 Cong. REc. H8469 (daily ed. Sept. 8, 1980).

289. President Reagan froze the issuance of new regulations by executive agencies for the first three months of his term. Presidential Memorandum of January 29, 1981, 46 Fed. Reg. 11,227 (1981). Since then, the number of new regulations issued has dropped significantly. See Statment of Frank S. Swaim, supra note 171, at 57-59.

290. January 1, 1981 to July $31,1981$.

291. See note 283 supra.

292. See 15 U.S.C. \& 634b-634d (1976 \& Supp. IV 1980). 
agencies that promulgates rules. These personnel collect certifications and IRFA's and scan the Federal Register for notices of proposed rules that may require agency action under the RFA. ${ }^{293}$ But the review process requires professionals, especially with respect to the review of certifications. ${ }^{294}$ Because the Office of Advocacy estimates that about seventy agencies promulgate rules that are potentially subject to the RFA, the Office with its limited staff should develop a priority list of the agencies that are of greatest concern to small entities and commit staff resources to their monitoring. As a practical matter, it may be necessary that the rules of some agencies go unreviewed if the Office is to do its job at all.

To assist the Office in its monitoring function, volunteers from the private sector can also be used to alert the staff to important rules. ${ }^{295}$ Furthermore, the Office can turn for assistance in regulatory analyses to other government agencies, particularly to the OMB. But that alliance, although critical to resolving the staffing problems facing the Office of Advocacy, will require careful attention.

3. The Office of Advocacy and the $O M B$. The overlap in jurisdiction between the OMB, which monitors the Paperwork Reduction Act and Executive Order 12,291,296 and the Chief Counsel inay create disputes and confusion, but it can also serve as a source of inutual support. The OMB, through its Office of Inforination and Regulatory Affairs, is an established organization well trained to conduct regulatory analysis. It has historically asserted strong control over the agencies within its jurisdiction and certainly can be expected to assert itself in any working relationship involving Executive Order 12,291 and the

293. The Office of Advocacy has drafted internal guides for RFA monitoring to assist its staff. See Office of Advocacy, Small Business administration, Guides to Regulatory FlexiBLITY ANALYSIS Monitoring (Draft 1981) (on file with Duke Law Library).

294. The Chief Counsel for Advocacy has established a rule-review process with five components: monitoring the Federal Register; logging of rules potentially subject to the RFA; review of these rules by a professional staff inember assigned to the particular agency; follow-up, as needed, and weekly assessment sessions by the Regulatory Flexibility Review Group. The Office is consistently exploring use of computer software that would be coinpatible with the OMB Reports Managenrent System. See Statement of Frank S. Swaim, supra note 171, at 14-15.

295. The Office of Advocacy has already appointed a task force of volunteers to assist in the monitoring process. So far over 200 unpaid inonitors, ntany of whon are attorneys who practice before the particular agencies involved, have been selected. Their role is primarily to serve as an early-warning systen and as a source of substantive guidance for the Office of Advocacy professionals who are assigned to specific agencies. In addition, many agencies have established RFA officials as contact and resource persons. See GUIDES TO Regulatory FlexibiLITY ANALYSIS Monitoring, supra note 293, at 26-80 (on file with Duke Law Library).

296. See text accompanying notes 237-38 and 245-49 supra. 
RFA. ${ }^{297}$ The question is to what extent the Chief Counsel may rely on OMB assistance in performing the monitoring role under the RFA without yielding the decisional authority of the Office of Advocacy. Obviously coordination is necessary, for otherwise the basic inessage of regulatory reform sent by the last two administrations and by the RFA itself would be ignored. On the other hand, coordination tends to create bureaucratic rivalries. For example, the sinall business community, whose chosen representative is the Chief Counsel, may well have special interests that the OMB does not consider important. Moreover, because Congress has clearly placed responsibility for small entities im the hands of the Office of Advocacy, the Office is unlikely to tolerate excessive OMB control. Because Congress and the President clearly want to minimize the burden of regulatory analysis, the Office of Advocacy and the OMB inust minimize any disagreements and work together. Recognizing that the OMB has the quantitative expertise to monitor agencies effectively, the Chief Counsel should rely on the OMB for special skills. ${ }^{298}$

\section{RELATIONSHIP OF THE RFA TO THE REgULATORY REFORM MOVEMENT}

The RFA is part of a broad moveinent toward regulatory analysis as a method of improving the performance of federal agencies. The RFA is the first such experiment to becone law; two omnibus bills which failed to pass in the Ninety-sixth Congress included regulatory analysis as centerpieces. 299 Because a strong impetus for regulatory analysis is in both the House and the Senate of the Ninety-seventh Congress, new legislation likely will be forthcoming and, if it is, the RFA and its regulatory-flexibility requirements will becoine a key part of the larger pattern of regulatory reform.

\section{A. The Regulatory Reform Proposals.}

Senator Laxalt has introduced a bill $(\mathrm{S} .1,080)$ to amend the APA by imposing regulatory analysis and review on all agencies that make

297. To some extent this integration has already occurred: the Executive Order ties directly into the RFA requirements. See notes 228-42 supra and accompanymg text.

298. Of course, the OMB has personnel limitations as well. The Office of Information and Regulatory Affairs has a staff of some 90 professionals, after gaining many of the former employees of the Council on Wage and Price Stability. See Eads, supra note 60, at 22-23. Because the OIRA has responsibility for the Paperwork Reduction Act and Executive Order 12,291, it is doubtful that it will have the capacity to do much RFA work unless that work relates to its regulatory analysis under the Executive Order.

299. See S. 1291, 96th Cong., Ist Sess., 125 CoNG. REc. S7128 (daily ed. June 6, 1979); S. 755, supra note 277. 
rules. ${ }^{300}$ Representative Danielson introduced a related bill (H.R. 746) in the House. ${ }^{301}$ Both bills provide for regulatory analysis of new rules, periodic review of existing rules, and publication of a regulatory agenda. In these respects they track similar requirements under the RFA. In other respects, llowever, they differ from the RFA.302

The bills impose standards of regulatory analysis that are more reminiscent of Executive Order 12,291 than of the RFA. For example, both bills deal with "major rules," measured in terms of impact. ${ }^{303}$ Furthermore, the type of analysis required is more of the technical costbenefit type than the general regulatory-flexibility type. The Senate bill requires that the statement of basis and purpose for a inajor rule include a "reasonable determination" that the benefits of the rule justify the cost and adverse effects of the rule. ${ }^{304}$ This aniounts to a requirement that cost-benefit analysis determine the outcoine of agency rulemaking, except when enabling legislation exphicitly dictates to the contrary. ${ }^{305}$ The House bill also requires preliminary and final regulatory analyses to be filed with each new rule, although it does not mandate strict comphance with cost-benefit methods. ${ }^{306}$ Both bills allow agencies to incorporate regulatory analyses froin other statutes. ${ }^{307}$

The bills provide for agency review of existing major rules over a ten-year period (which can be extended to fifteen if necessary). ${ }^{308}$ Each

300. S. 1080, 97th Cong., Ist Sess., 127 Cong. Rec. S4231 (daily ed. Apr. 30, 1981). The bill had 74 Senate co-sponsors. S. 1080 was passed by the Senate, with amendments, on March 24, 1982, by a vote of 94 to zero. 128 Cong. Rec. S2713 (daily ed. March 24, 1982).

301. H.R. 746, 97th Cong., 1st Sess., 127 Cong. REC. H73 (daily ed. Jan. 6, 1981).

302. The two bills also differ significantly from each other but these differences are not discussed unless they relate to the RFA.

303. See S. 1080, supra note 300 , at $§ 2(16)$; H.R. 746, supra note 301 , at $\S 621(3)$. The bills also mclude under the "major category," rules that have a significant adverse effect on health, safety or the environment and rules that the President designates as major. The House bill adds to regulatory analysis a category of "significant rules" that the agencies are to define according to the number of entities covered, the comphance and reporting requirements involved, the direct and indirect effects of the rule, and the rule's relationship to other rules. H.R. 746, supra note 301, at $\S 621(4)$.

304. See S. 1080 , supra note 300 , at $\$ 3(e)(2)$.

305. S. 1080 allows for legislation, such as the Oceupational Safety and Health Act of 1970 , Pub. L. No. 91-596, 84 Stat. 1590 (codified in various sections of 5, 15, 18, 29, 42, and 49 U.S.C.), which forbids cost-benefit analysis. See text accompanying notes 205-06 supra.

306. See H.R. 746, supra note 301 , at $\$ 622$. The analysis orignially required "an explanation of why an approach eutailing greater adverse economic effects was selected," id. $\$ 602(\mathrm{c})(5)(B)$, which did not, unlike the Senate bill, forbid non-cost justified outcomes. In the later revision of the House bill, cost justification of a proposed rule is more clearly demanded. Id. $\S 622(\mathrm{c})(5)(\mathrm{B})$ (amendment passed July 30, 1981).

307. S. 1080 , supra note 300 , at $\S 3(f)(4)$; H.R. 746 , supra note 301 , at $\S 622(d)(1)$. These bills do not directly mention the RFA but their drafters probably contemplated the RFA's requirement of regulatory-flexibility analysis.

308. See S. 1080 , supra note 300 , at $\S 560$; H.R. 746 , supra note 301 , at $\S 641$. 
bill also requires the establishment of regulatory agendas. Whereas the Senate bill requires an agency to publish in the Federal Register an agenda for all proposed rules and requires the "President or his designee" to publish a biannual list of major rules, ${ }^{309}$ the House bill requires agencies themselves to publish a regulatory agenda of major rules in the Federal Register on a biannual basis. ${ }^{310}$

Oversight responsibility for regulatory analysis also appears in the proposed bills. The Senate bill assumes that the justification for a major rule will be reviewed in its statement of basis and purpose as part of the rule. It places in the President "or an officer designated by him" the responsibility for reviewing existing rules and establishing the regulatory agenda. ${ }^{311}$ The House bill, which gives oversight responsibility over the final regulatory analysis to the OMB and to the courts, ${ }^{312}$ places overall responsibility im the Comptroller General of the United States to audit and to examine agency compliance with the regulatoryanalysis process and to make periodic reports to Congress. ${ }^{313}$

\section{B. The RFA and Regulatory Reform.}

On the solid assumption that some variation of the Senate and House bills will become law, a need to relate that legislation to the RFA and vice versa will arise, for recent congressional activity indicates no effort will be made to eliminate or to reduce drastically the role of the RFA in regulatory review. Because new legislation will largely implement the regulatory-analysis requirements currently imposed by Executive Order 12,291, much of the reconciliation process that now must take place between the Executive Order and the RFA would be relevant to new legislation. ${ }^{314}$ To the extent that the Office of Advocacy will already be familiar with the regulatory-flexibility process, the Chief Counsel should be able to protect the working of the RFA im any reconciliation between the RFA and new regulatory-reform legislation.

309. S. 1080 , supra note 300 , at $\$ 561$. The publication of major rules by the President is a function similar to that which President Carter's Regulatory Council performed.

310. H.R. 746, supra note 301 , at $\$ 631$. In addition, the bill instructs the President to publish a Calendar of Federal Regulations, which presents information on major rules from all agencies. Id. $\S 632$.

311. S. 1080 , supra note 300 , at $\$ 560(a)(2)$.

312. H.R. 746, supra note 301 , at $\$ \S 622$ (d)(3), 623. Section 624 of the bill provides: The Director of the Office of Management and Budget shall momitor and review compliance by agencies with the requirements of this subchapter and shall establish such procedures as may be necessary to ensure such compliance. The Director shall from time to time report to the President and the Congress on such agency comphance.

313. Id. $\$ 625$.

314. See notes $228-42$ supra and accompanying text. 
There are several ways, however, in which new legislation could reduce the importance of the RFA and the Office of Advocacy. If the House version becomes law and includes "significant" as well as inajor rules in the regulatory-analysis process, a potentially greater number of rules will be subject both to the RFA and to the cost-benefit type of regulatory analysis. Moreover, because the House bill replaces the regulatory agenda provisions of the RFA with its own regulatory-analysis format, further conflict will exist. ${ }^{315}$

The primary difficulty with the proposed legislation from the Office of Advocacy's viewpoint is the clear shift of mointoring responsibility from the Office of Advocacy to the OMB or other government authorities. ${ }^{316}$ This proposed shift suggests that the current overlap in responsibilities between the two organizations will be intensified; given the OMB's stature, further attempts to narrow the Chief Counsel's role in regulatory analysis seem inevitable. The Office of Advocacy, however, remaims politically important and any bureaucratic attempt to reduce its authority could create rumblings of support for the Office in Congress. ${ }^{317}$

Thus, the ultimate effect that enactment of generic regulatoryanalysis legislation will have on the RFA is difficult to calculate. In some ways the recogmition of regulatory analysis throughout government should have a positive effect on the regulatory-flexibility process. Agencies will becoine better trained to conduct regulatory analyses and more comfortable with concepts such as "tiering" that are of special importance to small entities. The small business community may worry that general reforms will tend to subordinate the special interests of small busmess to the overall interests of busmess generally, but whether Congress or the courts will permit this leveling effect to occur remams to be seen.

315. See H.R. 746, supra note 301, at $\S 631$, which eliminates section 602 of the RFA, 5 U.S.C. $\S 602$ (Supp. IV 1980) (dealing with the regulatory agenda). The House bill would require the RFA to enbrace the general regulatory agenda provisions of the new legislation. This approach certainly will reduce duphication and redundancy, but it will also eliminate special notice to small entities unless the Chief Counsel monitors and reports such agendas to sunall entities.

316. H.R. 746 gives control to OMB and the Comptroller General, but S. 1080 speaks in terms of the President or his designee. It is not inconceivable that the "designee" could in some situations becoine the Chief Counsel for Advocacy and thereby ensure a continued role for that Office and for the RFA. See 127 CoNG. REC. S12,318 (daily ed. Oct. 28, 1981) (remarks of Senator Nunn).

317. Such support has already emerged in the form of an amendment to S. 1080 offered by Senator Nunn which would return control for implenentation of the RFA to the Chief Counsel for Advocacy, thereby depriving the President of any option to place RFA oversight in OMB or other executive departments. See 127 CoNG. Rec. S12,318-19 (daily ed. Oct. 28, 1981). 


\section{CONCLUSION}

The RFA is a significant legislative achievement for small business. Given the current state of generic regulatory reform, the ultimate impact of the RFA is difficult to predict. Several factors, however, are currently observable that will aid in determining the RFA's importance. One factor is the effectiveness of the entity that must implement the RFA, the Office of Advocacy. The Office, if it carefully manages its power to reaci decisively to questionable certifications and weak analyses, can gam the attention of the agencies that must respond initially to the RFA's requirements.

Careful management requires not only a consolidation of efforts concerning the certifications and the IRFA's, but also an ability to work effectively with the OMB. Despite its preoccupation witl other regulatory-reform legislation, the OMB can provide the expertise necessary to assist the Office of Advocacy in becoming an effective oversight agency.

More importantly, the provisions of the RFA concerning judicial review deserve the Chief Counsel's attention. Although the RFA clearly does not contemplate an assertive judicial role in enforcing agency coinpliance with regulatory-flexibility analysis, there are ways in which the Chief Counsel can effectively intervene to alert the courts to the RFA and thereby increase agency imcentives for coinpliance. Finally, the Chief Counsel's reports to Congress and to the President can alert those branches of governinent to the importance of implementing the RFA.

Small business expects much froin the RFA, perhaps too much. The RFA does make agencies aware of the plight of small business, and this awareness can influence rulemaking proceedings just as it influenced congressional action. The RFA is special-interest legislation with a balance: it urges agencies to recognize differences in size when promulgating rules, but it does not undermine the agency's regulatory authority derived from organic legislation. Thus, while the RFA may not be all the small business community desires, it contains the seeds for producing workable compromises between government and the private sector and it does not pose unreasonable burdens on the administrative process. 


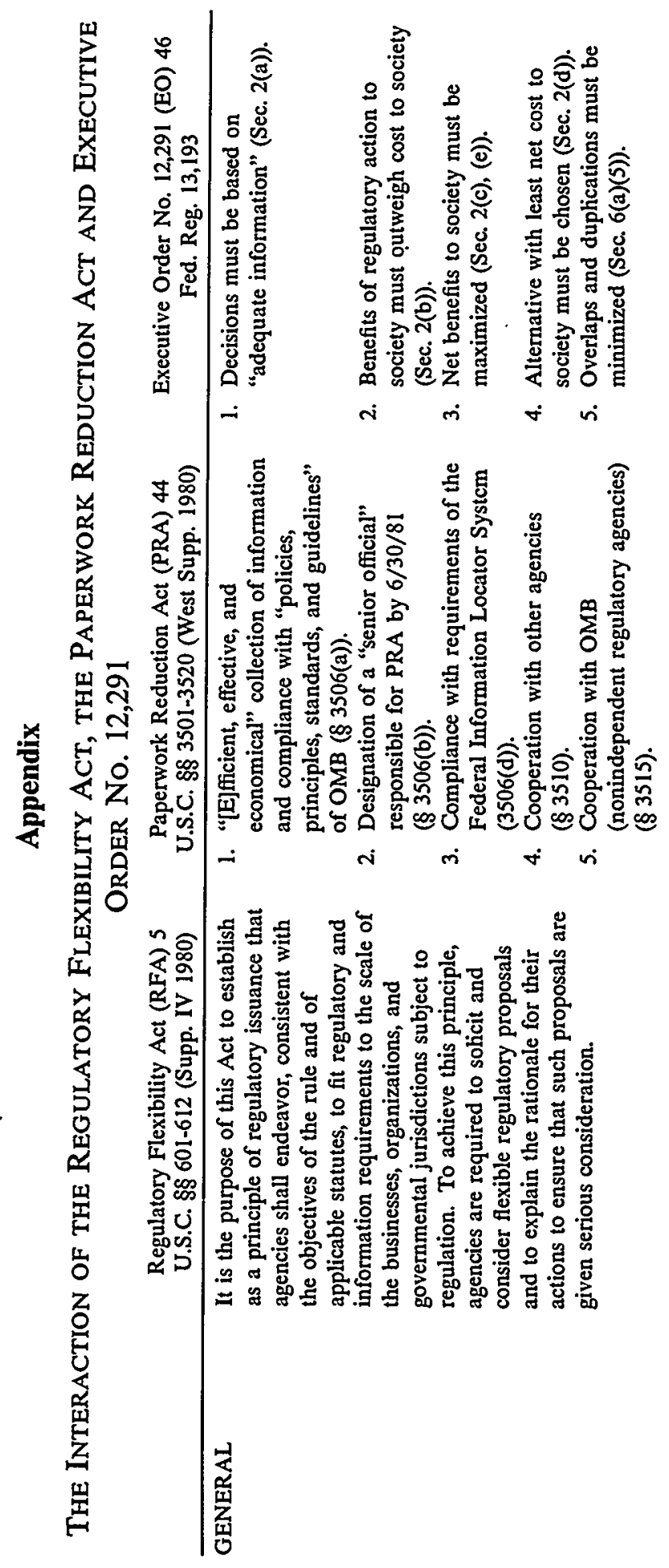




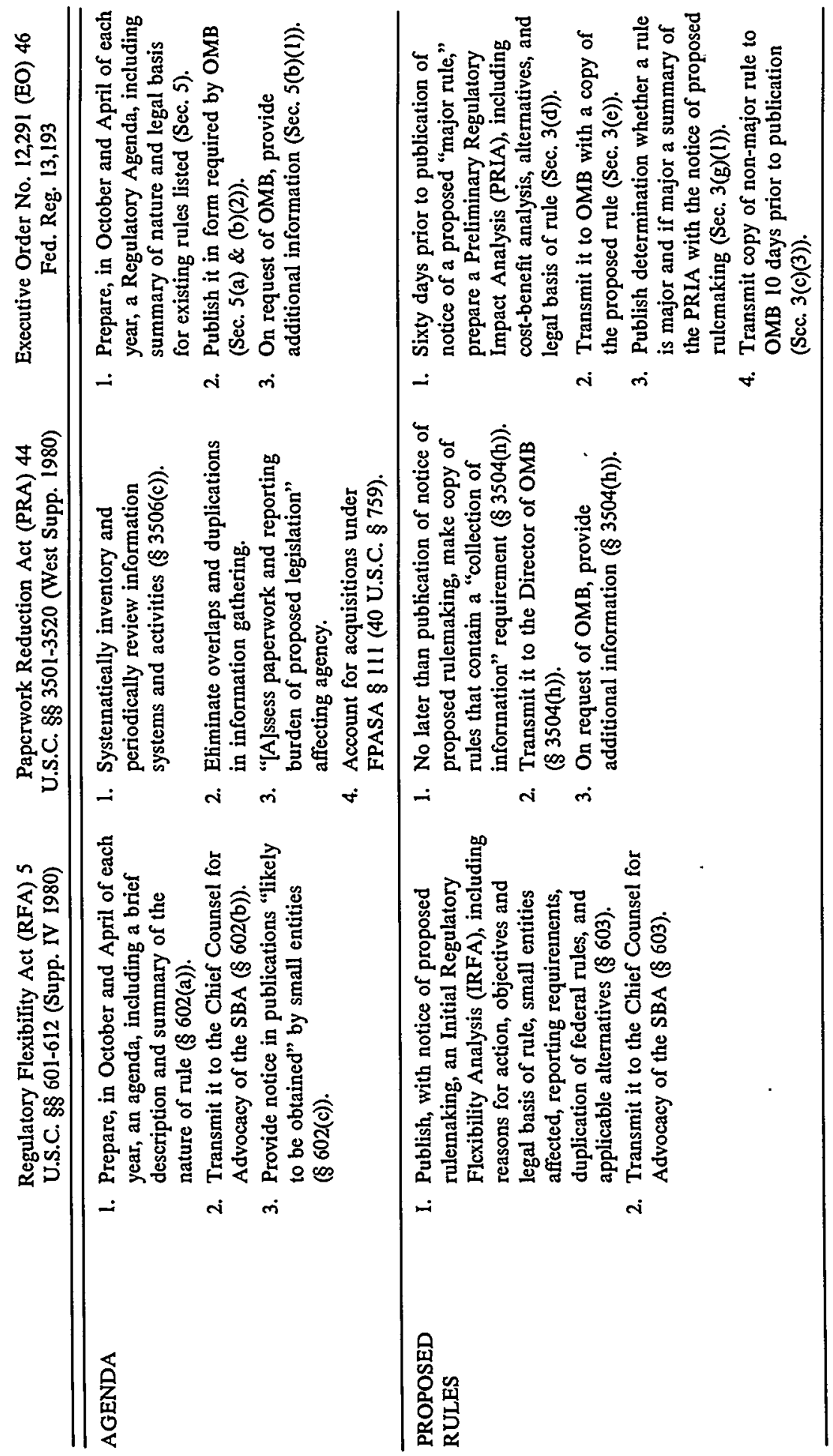




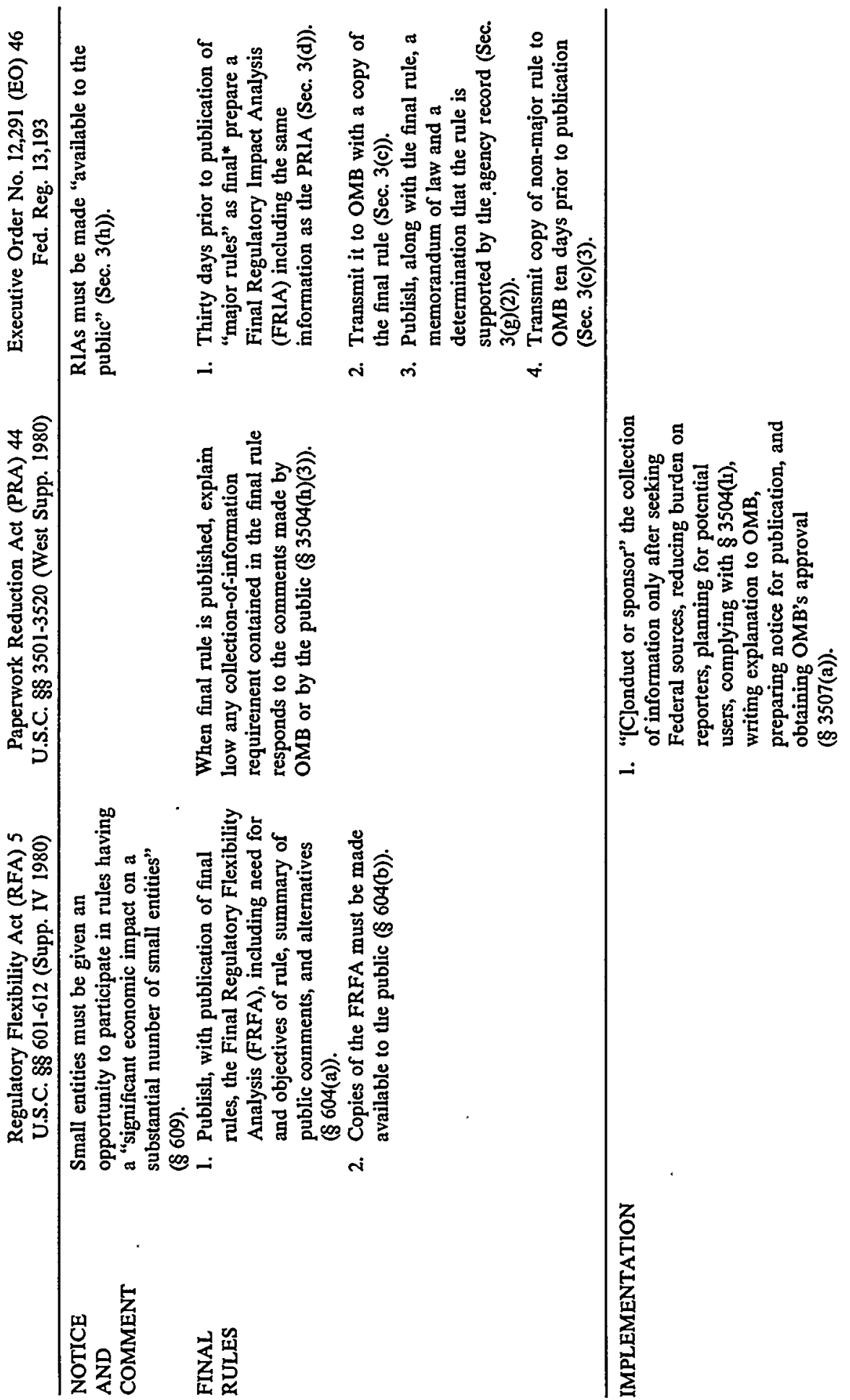




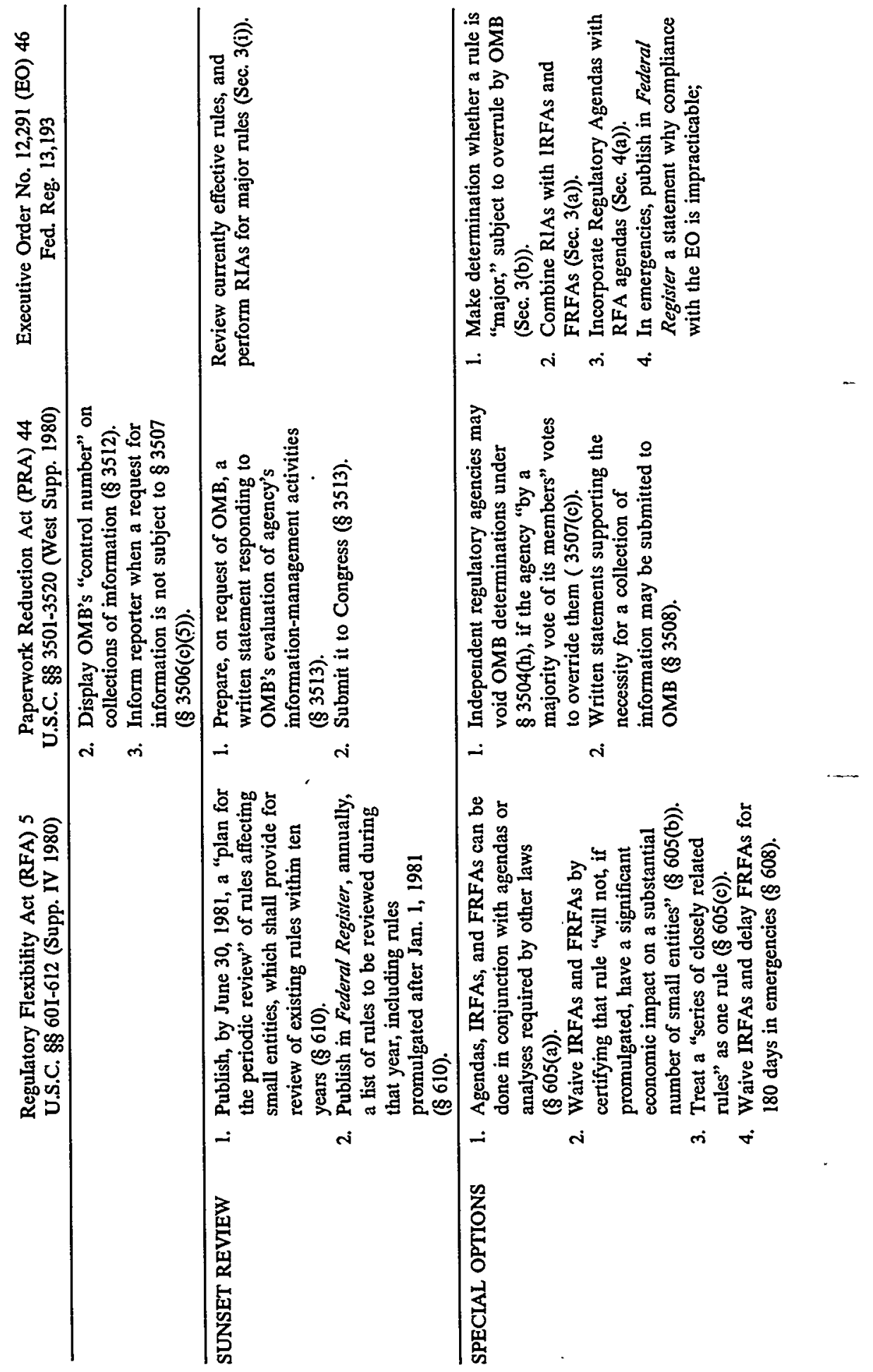




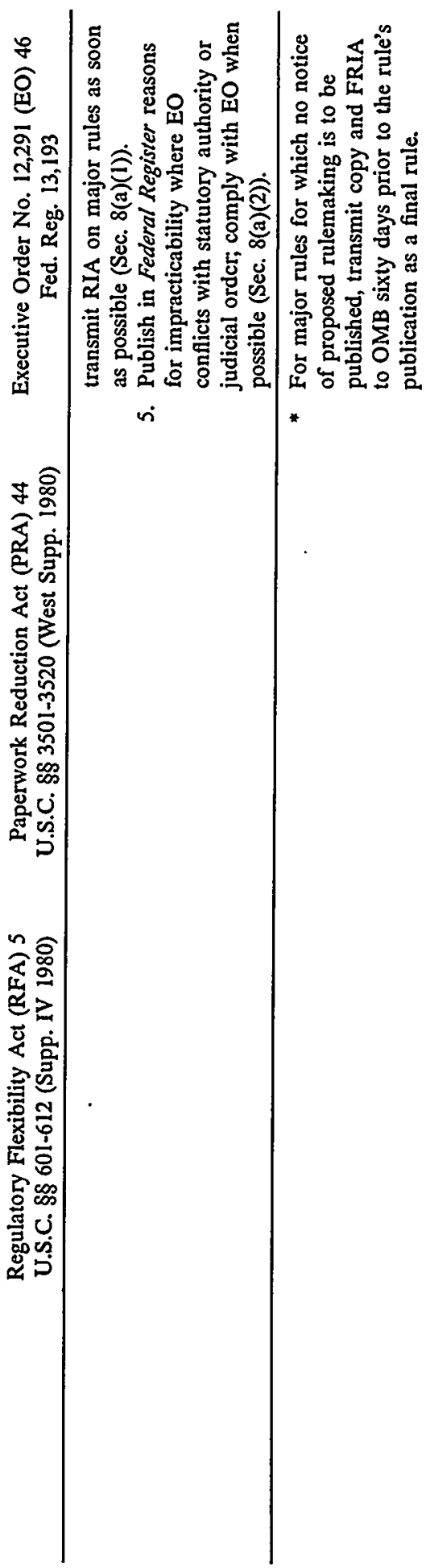

